\title{
Black carbon variability since preindustrial times in the eastern part of Europe reconstructed from Mt. Elbrus, Caucasus, ice cores
}

\author{
Saehee Lim ${ }^{1, a}$, Xavier Faïn ${ }^{1}$, Patrick Ginot ${ }^{1,2}$, Vladimir Mikhalenko ${ }^{3}$, Stanislav Kutuzov $^{3}$, Jean-Daniel Paris ${ }^{4}$, \\ Anna Kozachek ${ }^{3}$, and Paolo Laj ${ }^{1}$ \\ ${ }^{1}$ Univ. Grenoble Alpes, CNRS, IRD, Grenoble INP, IGE, 38000 Grenoble, France \\ ${ }^{2}$ Univ. Grenoble-Alpes, CNRS, IRD, Observatoire des Sciences de l'Univers, Grenoble, France \\ ${ }^{3}$ Institute of Geography, Russian Academy of Sciences, Moscow, Russia \\ ${ }^{4}$ Laboratoire des Sciences du Climat et de l'Environnement, IPSL, CEA-CNRS-UVSQ, CE Orme des Merisiers, \\ 91190 Gif sur Yvette, France \\ ${ }^{a}$ now at: Department of Earth and Environmental Sciences, Korea University, Seoul, South Korea \\ Correspondence to: Saehee Lim (saehee.lim@gmail.com)
}

Received: 8 September 2016 - Discussion started: 16 September 2016

Revised: 16 December 2016 - Accepted: 4 February 2017 - Published: 14 March 2017

\begin{abstract}
Black carbon (BC), emitted by fossil fuel combustion and biomass burning, is the second largest manmade contributor to global warming after carbon dioxide (Bond et al., 2013). However, limited information exists on its past emissions and atmospheric variability. In this study, we present the first high-resolution record of refractory BC ( $\mathrm{rBC}$, including mass concentration and size) reconstructed from ice cores drilled at a high-altitude eastern European site in Mt. Elbrus (ELB), Caucasus (5115 m a.s.1.). The ELB ice core record, covering the period 1825-2013, reflects the atmospheric load of $\mathrm{rBC}$ particles at the ELB site transported from the European continent with a larger $\mathrm{rBC}$ input from sources located in the eastern part of Europe. In the first half of the 20th century, European anthropogenic emissions resulted in a 1.5-fold increase in the ice core rBC mass concentrations with respect to its level in the preindustrial era (before 1850). The summer (winter) $\mathrm{rBC}$ mass concentrations increased 5-fold (3.3-fold) in 1960-1980, followed by a decrease until $\sim 2000$. Over the last decade, the rBC signal for summertime slightly increased. We have compared the signal with the atmospheric $\mathrm{BC}$ load simulated using past $\mathrm{BC}$ emissions (ACCMIP and MACCity inventories) and taken into account the contribution of different geographical regions to $\mathrm{rBC}$ distribution and deposition at the ELB site. Interestingly, the observed $\mathrm{rBC}$ variability in the ELB ice core record since the 1960s is not in perfect agreement with the simulated atmospheric BC load. Similar features between the ice core
\end{abstract}

$\mathrm{rBC}$ record and the best scenarios for the atmospheric $\mathrm{BC}$ load support anthropogenic BC increase in the 20th century being reflected in the ELB ice core record. However, the peak in BC mass concentration observed in $\sim 1970$ in the ice core is estimated to occur a decade later from past inventories. BC emission inventories for the period 1960s-1970s may be underestimating European anthropogenic emissions. Furthermore, for summertime snow layers of the 2000s, the slightly increasing trend of $\mathrm{rBC}$ deposition likely reflects recent changes in anthropogenic and biomass burning $\mathrm{BC}$ emissions in the eastern part of Europe. Our study highlights that the past changes in $\mathrm{BC}$ emissions of eastern Europe need to be considered in assessing ongoing air quality regulation.

\section{Introduction}

Climate forcing of black carbon (BC), a primary aerosol emitted by fossil fuel and biomass combustions, is of great concern due to its strong light-absorbing ability and small size, allowing it to be transported over long distances (Bond et al., 2013; Ramanathan and Carmichael, 2008). In highaltitude or high-latitude areas, $\mathrm{BC}$ has been identified as a significant contributor to accelerating snowmelt (Hansen and Nazarenko, 2004; Xu et al., 2016). Despite numerous studies through both measurements and model simulations (Bond et al., 2013, and references therein), little is known about BC's 
past variability, e.g., before year 2000, and sensitivity to climate change primarily due to limited in situ atmospheric BC measurements, both temporally and spatially (Collaud Coen et al., 2007, 2013).

Reconstruction of atmospheric BC variability from ice core archives can thereby be very helpful to understand past $\mathrm{BC}$ emissions and provide additional constraints on $\mathrm{BC}$ emission inventories (Bisiaux et al., 2012a; Kaspari et al., 2011; Legrand et al., 2007; McConnell et al., 2007; Wang et al., 2015). Particularly, the geographical proximity of the ice cores at high-altitude Alpine sites, e.g., European Alpine sites such as Col du Dôme, Colle Gnifetti and Fiescherhorn (Jenk et al., 2006; Legrand et al., 2013; Thevenon et al., 2009), to densely populated regions (approximately $\sim 100 \mathrm{~km}$ ) allows us to observe a fingerprint of BC emissions and past temporal variability in the anthropogenic source regions. In this respect, elemental carbon (EC) records reconstructed from ice cores at western European Alpine sites (Col du Dôme and Colle Gnifetti) highlight a pronounced EC increase starting mid 20th century (Legrand et al., 2007; Thevenon et al., 2009) with increasing anthropogenic activity in western Europe (Fagerli et al., 2007; Lamarque et al., 2010). It should be noted that EC refers to data derived from thermal methods which are different than optical methods providing $\mathrm{BC}$ (including $\mathrm{rBC}$ derived from incandescence methods; Petzold et al., 2013). However, recent EC records over the last 2 decades are not available from these western European ice cores, which makes it difficult to quantify historic $\mathrm{BC}$ emissions and thus provide implications for assessing European air quality regulation initiated since 1970 (Tørseth et al., 2012; Vestreng et al., 2007). Furthermore, long-term ice core $\mathrm{BC}$ records have never been reconstructed from the eastern European regions, where even atmospheric measurements are relatively scarce (Pio et al., 2007; Yttri et al., 2007). Reconstruction of $B C$ records with a wide range of coverage both temporally and spatially is crucial for understanding $\mathrm{BC}$ emission properties and establishing regulations on the emissions.

In this study, we present a high-resolution record of refractory $\mathrm{BC}(\mathrm{rBC})$ deposition to snow at a high-altitude site in Mt. Elbrus, Caucasus (5115 ma.s.1.), covering the period 1825-2013. Located between the Black and Caspian seas, Mt. Elbrus is influenced by a prevailing westerly from the European continent (Mikhalenko et al., 2015). For the first time, a high-resolution, continuous $\mathrm{rBC}$ record was extracted from ice cores over Europe. The Elbrus $\mathrm{rBC}$ record thus brings new and unique information on long-term variability and evolution of BC European emissions. The study documents the variability of $\mathrm{rBC}$ deposition and provides a comparison with the expected atmospheric BC variability based on past emission inventories, also considering atmospheric transport to the drilling site.

\section{Method}

\subsection{Ice core drilling site}

A $181.8 \mathrm{~m}$ long ice core (the 2009 core) was drilled at the western plateau of Mt. Elbrus (ELB), the highest summit of the Caucasus $\left(43^{\circ} 20^{\prime} 53,9^{\prime \prime} \mathrm{N}, 42^{\circ} 25^{\prime} 36,0^{\prime \prime} \mathrm{E}, 5115 \mathrm{~m}\right.$ a.s.l.; Fig. 1) in September 2009. In addition, a $20.5 \mathrm{~m}$ long ice core (the 2013 core) was extracted in June 2013 at the same site to expand the existing ice core sample set from 2009 to 2013. Drilling was performed in a dry borehole with a lightweight electromechanical drilling system, and was accompanied by borehole temperature measurements. Borehole temperatures ranged from $-17^{\circ} \mathrm{C}$ to $10 \mathrm{~m}$ depth to $-2.4^{\circ} \mathrm{C}$ at $181 \mathrm{~m}$ of the 2009 core (Mikhalenko et al., 2015).

The cores were packed in a polyethylene sealed bag and stored on the glacier at $-10^{\circ} \mathrm{C}$. After the drilling campaign, the cores were packed in insulated core boxes and shipped frozen to the cold laboratory of Lomonosov Moscow State University for preliminary investigation and water stable isotope analyses. In Moscow, the cores were split and one-half was shipped to Institut des Géosciences de l'Environnement (IGE; formerly Laboratoire de Glaciologie et Géophysique de l'Environnement, LGGE) in Grenoble, France, for additional analyses.

\section{2 $\mathrm{rBC}$ ice core analysis}

The top $156.6 \mathrm{~m}$ of the 2009 core and the entire 2013 core were analyzed at IGE in 2013-2014 and in 2014, respectively, using an ice core melter system coupled with a jet nebulizer (APEX-Q, Elemental Scientific Inc., Omaha, NE) and a single particle soot photometer (SP2, Droplet Measurement Technologies, Boulder, Colorado). We have used the terminology proposed by Petzold et al. (2013) for incandescencebased BC measurements. Our results are therefore reported in terms of refractory BC. It should be noted that there is a direct relationship (although not necessarily linear) between $\mathrm{rBC}$ and $\mathrm{BC}$ measured with other techniques (Kondo et al., 2011a; Laborde et al., 2012; Miyakawa et al., 2016).

Dust and conductivity are continuously analyzed simultaneously to rBC. Briefly, ice core sticks $(3.4 \mathrm{~cm} \times 3.4 \mathrm{~cm} \times 1 \mathrm{~m})$ were melted at a mean rate of $3 \mathrm{~cm} \mathrm{~min}^{-1}$ and the meltwater from the inner $6.8 \mathrm{~cm}^{2}$ of the sticks was continuously collected. After de-bubbling, the sample flow was split to a rBC analytical line with a mean flow of about $70 \pm 10 \mu \mathrm{L} \mathrm{min}^{-1}$. The flow rate dedicated to $\mathrm{rBC}$ analyses was continuously recorded using a mass flow meter (SENSIRION ${ }^{\odot}$ SLI-2000). In parallel, the meltwater was sampled by two auto-samplers at the end of the CFA for offline ionic species analysis and archive storage. The upper section of the 2009 firn core (surface to $7.2 \mathrm{~m}$ depth) was analyzed discretely.

Ice core $\mathrm{rBC}$ analysis using the SP2 has been reported previously (Bisiaux et al., 2012a, b; Ginot et al., 2014; Jenk- 

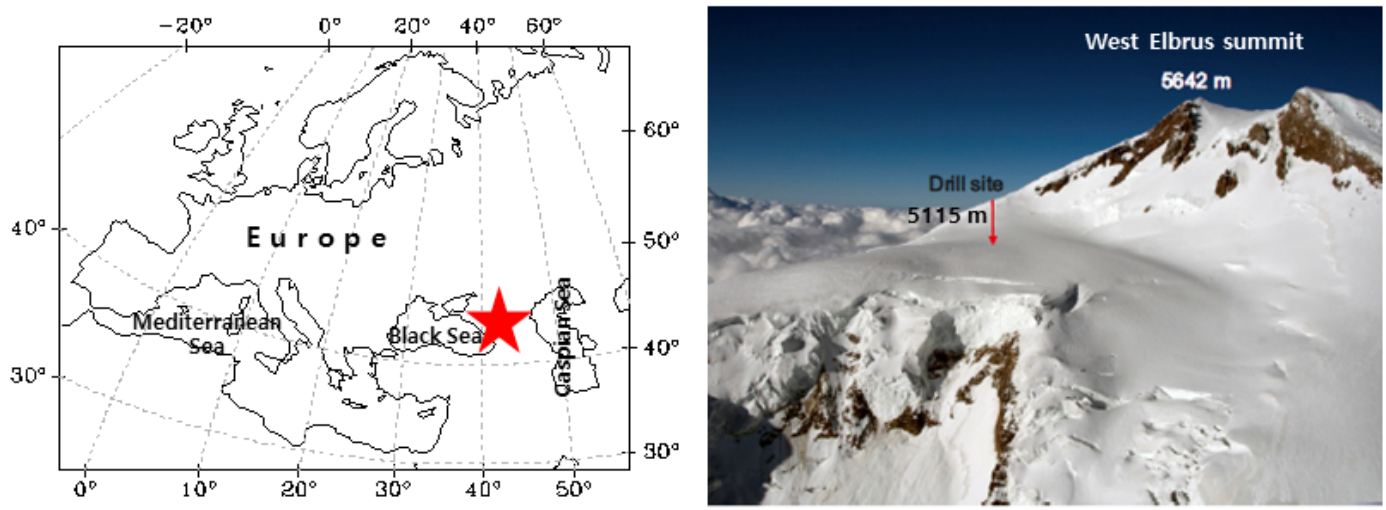

Figure 1. Location of the ice core drilling site $\left(43^{\circ} 20^{\prime} 53,9^{\prime \prime} \mathrm{N}, 42^{\circ} 25^{\prime} 36,0^{\prime \prime} \mathrm{E}, 5115 \mathrm{~m}\right.$ a.s.l., indicated by the red star or arrow) at the Mt. Elbrus, western Caucasus, mountain range between the Black and Caspian seas.

ins et al., 2013; Kaspari et al., 2014; Wang et al., 2015). Specifically, recent papers describe a detailed analytical evaluation for $\mathrm{rBC}$ in liquid samples, e.g., rain, snow and ice cores, using the SP2 (Lim et al., 2014; Mori et al., 2016; Schwarz et al., 2012; Wendl et al., 2014). The SP2 uses a laser-induced incandescence method to measure the mass of individual rBC particles (Schwarz et al., 2006; Stephens et al., 2003). Briefly, an individual $\mathrm{rBC}$ particle passes through the laser beam intra-cavity of a $1064 \mathrm{~nm} \mathrm{Nd:YAG} \mathrm{laser} \mathrm{and}$ incandescences. Of two PMT photodetectors (broad and narrow bands) that are used to detect the incandescence signal, we used only the broadband detector to derive the rBC mass, avoiding a low signal-to-noise ratio from the narrowband detector. The SP2 was calibrated by analyzing mass-selected fullerene soot (Alfa Aesar Inc., USA). The design and gain settings of our SP2 resulted in the lower and upper limits of measurements for $\mathrm{rBC}$ mass being $\sim 0.3-220 \mathrm{fg}$. A particle larger than $220 \mathrm{fg}$ was treated as the particle of $220 \mathrm{fg}$. Loss of $\mathrm{rBC}$ particles occurring during aerosolization in the APEX-Q was calibrated and corrected daily using rBC standard solutions (Aquadag ${ }^{\circledR}$, Acheson Inc., USA; eight steps from 0.1 to $100 \mu \mathrm{g} \mathrm{L}^{-1}$ ), which resulted in a $\mathrm{rBC}$ mass recovery of $75 \pm 7 \%$. The rBC fraction that was not aerosolized was partially identified in drains and the internal surface of the APEX-Q (see the Supplement in Lim et al., 2014). To prevent contamination and achieve rBC levels as low as possible, both an instrumental blank (ultrapure water) and a $5 \mathrm{~cm}$ procedure blank (frozen ultrapure water cut in the cold room) were run daily prior to field sample analysis, until the $\mathrm{rBC}$ counting reached 0 to $1 \mathrm{~s}^{-1}$, equivalent to a $\mathrm{rBC}$ concentration of less than $0.01 \mu \mathrm{g} \mathrm{L}^{-1}$.

High-resolution continuous $\mathrm{rBC}$ data recorded every second were smoothed at a depth resolution of $1 \mathrm{~cm}$, except for the upper section (surface to $7.2 \mathrm{~m}$ depth) of the 2009 core that was discretely analyzed at a depth resolution of $\sim 5$ $10 \mathrm{~cm}$. The density of $\mathrm{rBC}$ data points per year $(N=8 \sim 376)$ depends on annual snow accumulation rates and ice thinning with depth. The two ice cores are overlapped for snow layers of years 2007-2009 (Fig. S1 in the Supplement). The records described here for $\mathrm{rBC}$ concentrations are (i) the 2009 ice core from 2.9 to $156.6 \mathrm{~m}$, corresponding to calendar years 1825-2008, and (ii) the top $15.9 \mathrm{~m}$ of the 2013 core, corresponding to calendar years 2009-2013. These two ice core records cover the calendar years 1825-2013.

As a first survey of long-term $\mathrm{rBC}$ size distributions of the ice core record, the mass equivalent diameter of a measured single $\mathrm{rBC}$ particle, $D_{\mathrm{rBC}}$, was calculated, assuming a void-free $\mathrm{BC}$ density of $1.8 \mathrm{~g} \mathrm{~cm}^{-3}$ (Moteki and Kondo, 2010). The calculated $D_{\mathrm{rBC}}$ was in the range of $\sim 70$ and $620 \mathrm{~nm}$. A series of tests using mono-dispersed polystyrene latex (PSL) spheres with known diameters (150-600 nm) and poly-dispersed standard BC (Aquadag ${ }^{\circledR}$ ) suggests that the APEX-Q/SP2 system preserves the original size information of $\mathrm{rBC}$ particles in liquid samples and provides highly reproducible $\mathrm{rBC}$ size measurements with a variation of $<5 \mathrm{~nm}$ (Sect. 2.2.3 and 2.2.5 in Lim et al., 2014; Wendl et al., 2014). rBC size distributions were retrieved seasonally and fitted with a $\log$-normal fit with a bin size (no.) $=200$. The mass mode diameter (MMD) of the log-normal fit was then extracted to further reduce parameters. Size intervals between bin channels vary, with the minimum interval of less than $8 \mathrm{~nm}$ for the MMD $200-350 \mathrm{~nm}$. Here, all SP2 data were processed with the SP2 toolkit developed by M. Gysel at the Paul Scherrer Institute (PSI, Switzerland; http://aerosolsoftware. web.psi.ch/).

\subsection{Ice core dating and seasonal signature}

Ice core dating was determined by counting annual layers from 1825 to 2013 using the seasonal cycles of ammonium $\left(\mathrm{NH}_{4}^{+}\right)$, succinic acid and water stable isotopes $(\delta \mathrm{D}$ and $\delta^{18} \mathrm{O}$ ) that were analyzed discretely. Based on the examination of the ammonium and succinic acid profiles, each annual layer was divided into two parts corresponding to snow deposition under winter conditions and summer conditions (Legrand et al., 2013; Mikhalenko et al., 2015; Preunkert et 
al., 2000). In addition, the annual layer counting was further confirmed using the reference horizon from a tritium peak (1963) and a volcanic horizon (Katmai in 1912). The mean annual net accumulation rate of $1455 \mathrm{~mm}$ w.e. for the last 140 years was estimated from these proxies. The dating uncertainty is 2 years between the top and $106.7 \mathrm{~m}$ (Kozachek et al., 2016; Mikhalenko et al., 2015) and probably larger below $106.7 \mathrm{~m}$ due to ice thinning. Further details on dating are found in Mikhalenko et al. (2015).

Ice core seasonality was determined by the ammonium stratigraphy and further verified by the isotope variations. However, seasonal separation of the high-resolution $\mathrm{rBC}$ record made by the lower-resolution ammonium profile was sometimes challenging, particularly at the edge of two seasons, misleading winter (summer) rBC layers to be more concentrated (less concentrated) by the adjacent seasonal rBC layer. To avoid inaccurate separation of an annual ice layer into winter and summer intervals, only mid-summer and mid-winter $\mathrm{rBC}$ concentrations were extracted by considering data comprised between the 25 th percentile and the 75 th percentile of the depth thickness of each seasonal snow layer. This seasonal separation method is fairly supported by the fact that (i) observed precipitation in the western Caucasus is equally distributed throughout a year (e.g., at Klukhorskiy Pereval station located at $2037 \mathrm{~m}$ a.s.1., $50 \mathrm{~km}$ westward from the drilling site: $52 \%$ of the annual precipitation (or $48 \%$ ) is observed during summer (or winter) and each monthly precipitation accounts for $6-11 \%$ of the total precipitation for the period 1966-2009; www.meteo.ru) and (ii) maximum or minimum values of both $\delta^{18} \mathrm{O}$ and ammonium coincide for most of the Elbrus core annual ice layers. The mid-summer and mid-winter therefore correspond roughly to the warmest 3 months and the coldest 3 months ("background winter") of a year. Later in the paper, the summer and winter of this study will refer to mid-summer and mid-winter, respectively.

\subsection{Atmospheric transport modeling}

\subsubsection{Model description and runs}

The FLEXPART v6.2 Lagrangian particle dispersion model (LPDM) calculates the trajectories of tracer particles using the mean winds interpolated from the gridded analysis field and parameterizations representing turbulence and convective transport (Forster et al., 2007; Stohl and Thomson, 1999). FLEXPART was run using reanalysis fields of the European Centre for Medium-Range Weather Forecasts (ECMWF, ERA-Interim) at $0.75^{\circ} \times 0.75^{\circ}$ resolution, which has been available since 1979 . Here, a backward simulation mode was used to analyze particle transport pathways from potential flux regions to the sampling site (Seibert and Frank, 2004; Stohl et al., 2005).

To limit computational cost, simulations were performed for two selected periods: 2005-2009 and 1979-1983. We selected these periods because (i) year 1979 is the first year of

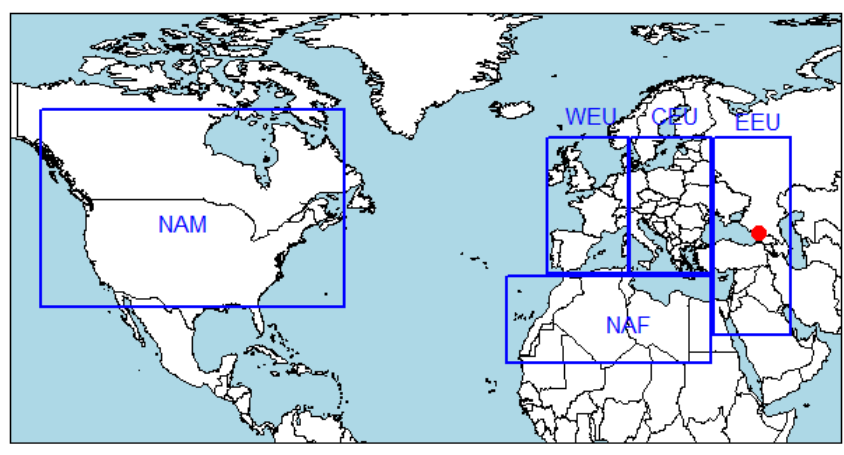

Figure 2. The five sub-regions classified as potential $\mathrm{rBC}$ emission source regions. The Elbrus drilling site is indicated by a red circle. WEU, CEU, EEU, NAF and NAM represent western Europe, central Europe, eastern Europe, northern Africa and North America, respectively.

ECMWF data and year 2009 is the last year of our longer ice core (2009 ice core) that was analyzed prior to the 2013 ice core, and (ii) these years show inflection in $\mathrm{rBC}$ trends (Sect. 3.2). It would thus be sufficient to analyze transport patterns influencing rBC at ELB and determine potential changes in these transport patterns. In simulations, 1000 particles are released at the drilling site during every 5-day interval in June to August (JJA) and in December to February (DJF). Modeled global average atmospheric lifetimes of BC particles vary by a factor of more than 3 , ranging from 3 to 10 days (Bond et al., 2013). Because BC particles reaching the high-altitude ELB site would experience longer lifetimes than the particles transporting in the planetary boundary layer (PBL), simulations were performed using BC lifetimes of 5 and 7 days. However, 7-day air mass trajectories extended to the Pacific and therefore made little difference to the 5-day simulations. Thus we set the BC lifetime to 5 days. The number of particles was then computed every $3 \mathrm{~h}$ at $0.5^{\circ} \times 0.5^{\circ}$ resolution.

\subsubsection{Sensitivity by potential source regions}

The finally defined footprint density $F(i, j, n)$ is expressed as a parameter encompassing released particle number and residence time along the particles' pathway, in procedure defined unit (p.d.u.). This final result is theoretically identical to potential emission sensitivity (PES), called the sourcereceptor relationship by Seibert and Frank (2004), which is proportional to the particle residence time in a particular grid cell with a fixed altitude range.

To facilitate analysis we reduced the number of variables from the gridded footprint density by summing them over large regions. We classified the footprint areas into five geographical regions with specific $\mathrm{rBC}$ emission sources (Fig. 2). The regions identified are as follows: EEU (eastern Europe including nearby Mt. Elbrus, Ukraine and European Russia and a part of the Middle East), CEU (central Eu- 
(a)

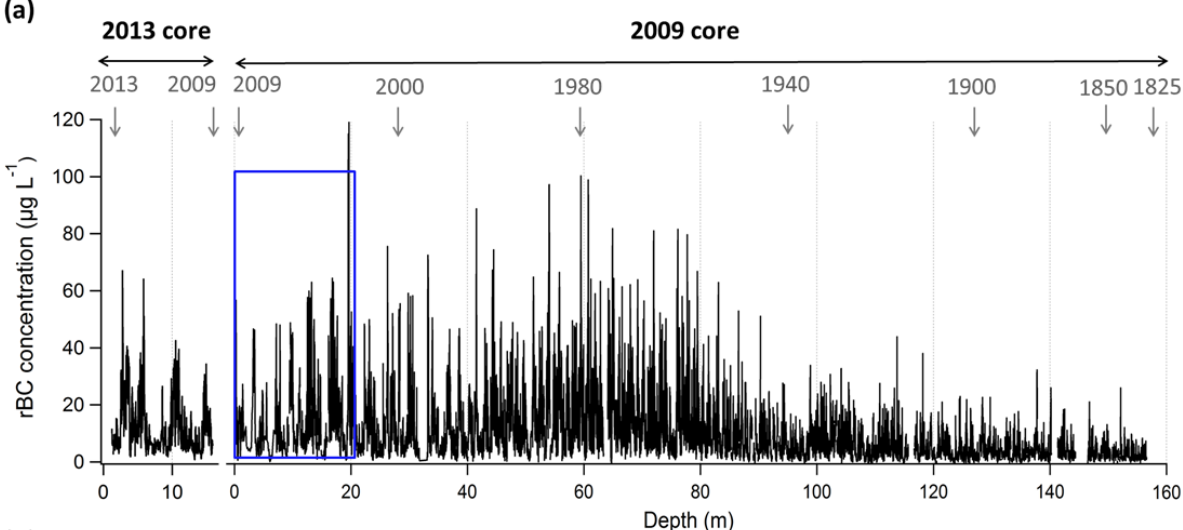

(b)

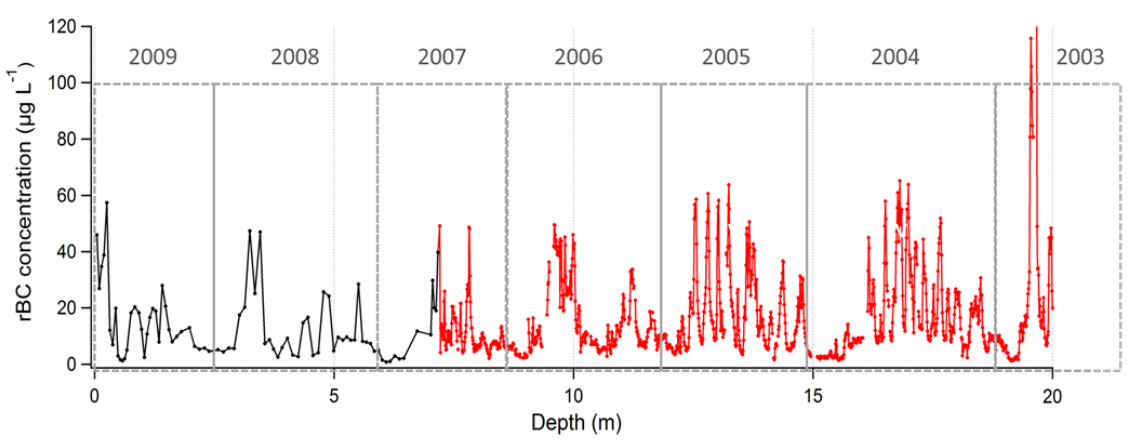

Figure 3. A profile of high-resolution rBC concentrations of Mt. Elbrus ice cores. (a) Whole rBC profile of both the 2013 core and the 2009 core, and (b) the 2009 core from the top to $20 \mathrm{~m}$ corresponding to the blue region in (a). In (b), lower-resolution (at $\sim 5-10 \mathrm{~cm}$ resolution; black color) and high-resolution (at $1 \mathrm{~cm}$ resolution; red color) $\mathrm{rBC}$ profiles obtained from discrete analysis and continuous flow analysis, respectively, are shown. For a whole rBC record, a section of lower-resolution signals of the 2009 core (corresponding to calendar year 2009) was replaced with the high-resolution rBC signals of the 2013 core. Gray text at the top of the figures stands for the calendar year corresponding to the ice core depth.

rope), WEU (western Europe), NAF (northern Africa), NAM (North America) and Others (the Atlantic and a part of northern Europe above $60^{\circ} \mathrm{N}$ ).

To display our results, we first calculate the footprint density $F_{\mathrm{e}}$ of the entire footprint area:

$F_{\mathrm{e}}(i, j)=\sum_{n=1}^{N} F(i, j, n)$.

Here, $F(i, j, n)$ is the footprint density, where $i$ and $j$ are the indices of the latitude-longitude grid and $n$ runs over the total number of cases $N . F_{\mathrm{e}}$ indicates the entire footprint area where the aerosols track during the last 5 days of transport. Note that we found little inter-annual variability in the footprint contribution of each region to the ELB site, with a $3 \%$ variation over the two periods (2005-2009 and 1979-1983). Assuming that this inter-annual variability in footprint density is not large enough to influence long-term $\mathrm{rBC}$ trends and that the results over the two periods are thus fairly representative of the 20th century, we combined the simulation results and used this approach to study the long-term emission contribution of each geographical region to $\mathrm{rBC}$ distribution and deposition at our drilling site.
In addition to the calculation using total particles in the atmospheric column, calculations using particles positioned in the lowest $2 \mathrm{~km}$ layers in the atmosphere were performed to investigate emission source regions of aerosols transporting from low altitudes, while the simulation procedure is the same as for the entire atmospheric column. To show the potential particle transport strength of each region relative to the entire area, we calculated the percentages of the footprint density in each region relative to the one in the entire area. To do this, we sum $F_{\mathrm{e}}(i, j)$ over the entire footprint area, resulting in one value. In the same way, we $\operatorname{sum} F(i, j)$ within each of the five regions, resulting in five values.

\subsection{Historic BC emission inventories}

To describe temporal variability in the regional $\mathrm{BC}$ emissions and atmospheric load of BC transported to the ELB site, we used time-varying anthropogenic and biomass burning BC emissions estimated by the ACCMIP (Emissions for Atmospheric Chemistry and Climate Model Intercomparison Project) inventory for the period 1900-2000 on the decadal scale (at $0.5^{\circ} \times 0.5^{\circ}$ resolution; Lamarque et al., 2010) the 
and MACCity (MACC/CityZEN EU projects) inventory for the year 2008 (at $0.5^{\circ} \times 0.5^{\circ}$ resolution; (Diehl et al., 2012; Granier et al., 2011; Lamarque et al., 2010; van der Werf et al., 2006). Note that the ACCMIP inventory provides decadal means (e.g., "1980" corresponds to the mean of 1980-1989) for the biomass burning estimates and representative values (e.g., "1980" is a representative of 1975-1985) for the anthropogenic estimates, leading to a 5-year shift between the two estimates. We used anthropogenic emission only for constraining BC emissions in DJF and both anthropogenic and biomass burning emissions for constraining $\mathrm{BC}$ emissions in JJA, because seasonal biomass burning $\mathrm{BC}$ emissions are maximized in summertime (May to August), being 2 orders of magnitude larger than that of wintertime (September to February) with respect to anthropogenic emissions occurring year-round (Lamarque et al., 2010).

\section{Results and discussion}

\subsection{High-resolution $\mathrm{rBC}$ record from Elbrus ice cores}

We present the first high-resolution $\mathrm{rBC}$ record of ice cores drilled in Mt. Elbrus, Caucasus (2009 and 2013 cores, Fig. 3a). The rBC concentrations along the two cores ranged from 0.01 to $222.2 \mu \mathrm{g} \mathrm{L}^{-1}$ with a mean $\pm 1 \sigma$ of $11.0 \pm 11.3 \mu \mathrm{g} \mathrm{L}^{-1}$ and a median of $7.2 \mu \mathrm{g} \mathrm{L}^{-1}$. A $20 \mathrm{~m}$ long section is zoomed in Fig. $3 \mathrm{~b}$ to highlight the higher resolution of $\mathrm{rBC}$ signals when continuously recorded at a $1 \mathrm{~cm}$ depth interval compared to the surface snow and firn section (from top to $7.2 \mathrm{~m}$ ) analyzed discretely at a $\sim 5-10 \mathrm{~cm}$ depth interval. The $\mathrm{rBC}$ record was found to preserve sub-annual variability from the top to a depth of $156.6 \mathrm{~m}$, with $\mathrm{rBC}$ spikes reflecting large and abrupt variability in deposition of atmospheric rBC particles. Such a high-resolution record brings new opportunities to study dynamic atmospheric vertical transport and/or sporadic events in a season.

A well-marked seasonal rBC cycle (e.g., Fig. 3b) was characterized for the 2013 core and the 2009 core down to $156.6 \mathrm{~m}$ by consistent high summer values ranging from 0.2 to $222.2 \mu \mathrm{g} \mathrm{L}^{-1}$ with a mean $\pm 1 \sigma$ of $15.5 \pm 12.9 \mu \mathrm{g} \mathrm{L}^{-1}$ and a median of $11.7 \mu \mathrm{g} \mathrm{L}^{-1}$ and low winter values ranging from 0.2 to $44.6 \mu \mathrm{g} \mathrm{L}-1$ with a mean $\pm 1 \sigma$ of $5.9 \pm 5.1 \mu \mathrm{g} \mathrm{L}^{-1}$ and a median of $4.5 \mu \mathrm{g} \mathrm{L}^{-1}$ (Table 1). The highest $\mathrm{rBC}$ mass concentration of an annual snow layer was observed in the summer snow layer. In atmospheric observations at ground-based sites in the western and central Europe boundary layer, EC aerosol mass concentrations in winter are higher roughly by a factor of 2 than in summer, mainly due to the enhanced domestic heating (Pio et al., 2007; Tsyro et al., 2007). In contrast to the boundary-layer sites, the atmospheric measurements at high-elevation sites in Europe (e.g., Puy de Dôme at $1465 \mathrm{~m}$ a.s.l., Sonnblick at $3106 \mathrm{~m}$ a.s.l. and Jungfraujoch at $3580 \mathrm{~m}$ a.s.1.) revealed 2 to 3 times higher EC levels during summer than winter (Bukowiecki et al., 2016; Pio et al.,
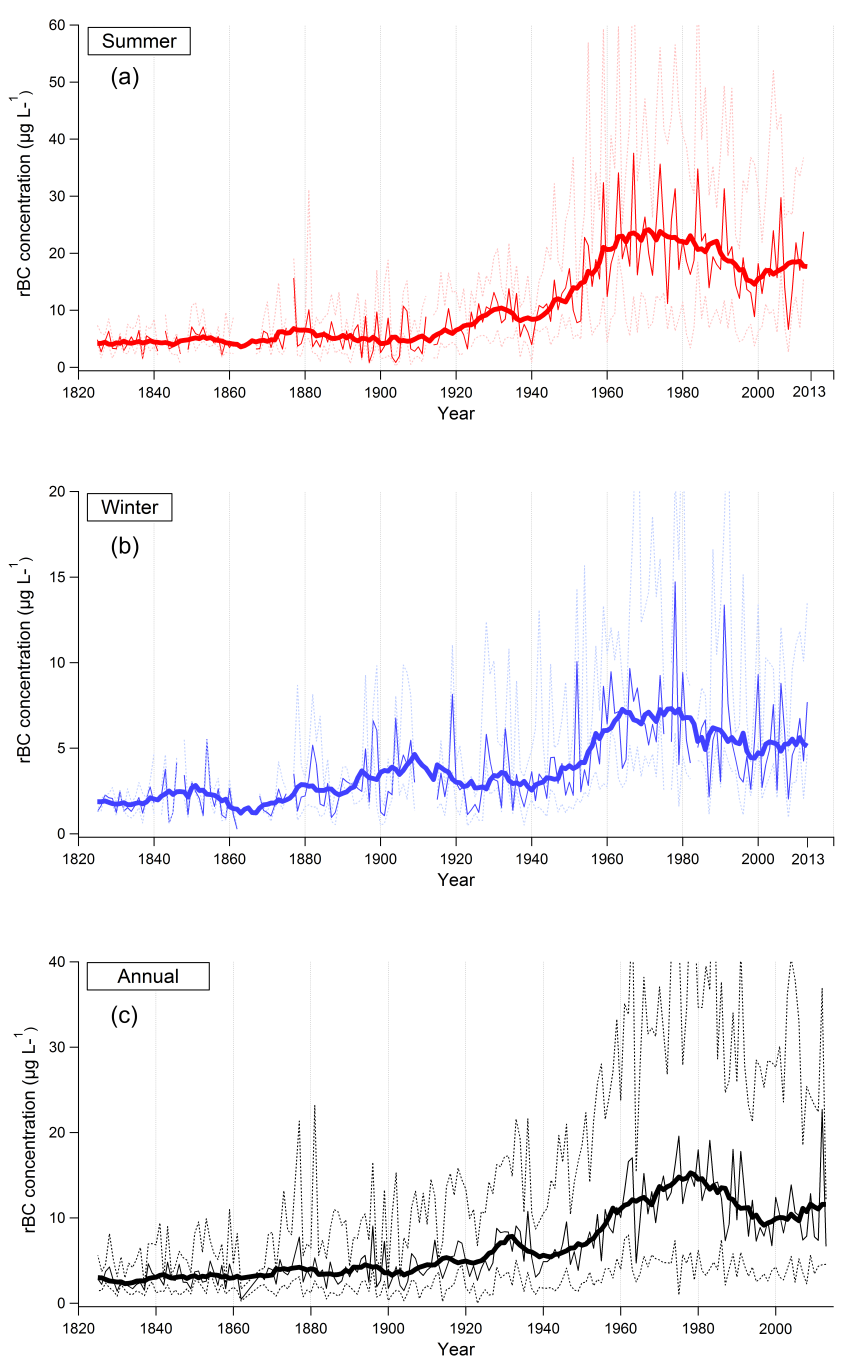

Figure 4. Annually averaged temporal evolution in the rBC mass concentration of the ELB ice cores. (a) Summer, (b) winter, and (c) annual variabilities. The thin solid line is medians and the dashed lines are the lower and upper 10th percentiles of the seasonal or annual $\mathrm{rBC}$ values. The upper 10th percentiles do not exceed 75, 35, and $56 \mu \mathrm{g} \mathrm{L}^{-1}$ for summer, winter, and annual, respectively. The thick lines are 10-year smoothing of medians. Discontinuous thin lines indicate ice layers with unclear seasonality or unanalyzed ice layers. Note the different $y$ scales for three time series of rBC concentrations.

2007; Venzac et al., 2009), reflecting the efficient upward transport of BC aerosols from the polluted boundary layer to the high altitudes during summer, primarily by thermally driven convection and thickening boundary-layer height ( $\mathrm{Lu}-$ gauer et al., 1998; Matthias and Bosenberg, 2002). This is consistent with the $\mathrm{rBC}$ seasonality observed in the ELB ice core. 
Table 1. rBC mass concentrations at seasonal resolution and relative increases compared to 1825-1850 (preindustrial era) for different time periods.

\begin{tabular}{|c|c|c|c|c|}
\hline \multirow[t]{2}{*}{ Time period } & \multicolumn{2}{|c|}{ Summer } & \multicolumn{2}{|c|}{ Winter } \\
\hline & $\begin{array}{r}\text { Concentration } \\
\text { in } \mu g \mathrm{~L}^{-1} \\
(\text { median } \pm \mathrm{SD})\end{array}$ & $\begin{array}{r}\text { Relative } \\
\text { increase } \\
\text { to } 1825-1850\end{array}$ & $\begin{array}{r}\text { Concentration } \\
\text { in } \mu \mathrm{g} \mathrm{L}^{-1} \\
(\text { median } \pm \mathrm{SD})\end{array}$ & $\begin{array}{r}\text { Relative } \\
\text { increase } \\
\text { to } 1825-1850\end{array}$ \\
\hline $1825-1850$ & $4.3 \pm 1.5$ & 1.0 & $2.0 \pm 0.9$ & 1.0 \\
\hline $1850-1900$ & $5.3 \pm 2.6$ & 1.1 & $2.5 \pm 1.4$ & 1.0 \\
\hline 1900-1950 & $7.9 \pm 3.9$ & 1.5 & $3.2 \pm 1.6$ & 1.4 \\
\hline $1950-2000$ & $20.0 \pm 7.1$ & 4.3 & $6.0 \pm 2.7$ & 2.7 \\
\hline 1960-1980 & $22.6 \pm 7.2$ & 5.0 & $7.1 \pm 2.5$ & 3.3 \\
\hline 2000-2013 & $17.7 \pm 5.9$ & 3.9 & $5.4 \pm 2.3$ & 2.4 \\
\hline
\end{tabular}

\subsection{Long-term evolution of $\mathrm{rBC}$ mass concentrations}

Time series of seasonal (summer and winter) and annual medians of rBC mass concentrations from 1825 to 2013 are shown in Fig. 4. Medians are shown with the lower and upper 10th percentiles to illustrate $\mathrm{rBC}$ concentrations. The $\mathrm{rBC}$ concentrations varied significantly over the past $\sim 190$ years, with a large inter-annual variability. Summer, winter and annual $\mathrm{rBC}$ medians increased gradually since the onset of the 20th century, with a rapid increase in $\sim 1950$ lasting until $\sim 1980$. Ten-year moving averaged $\mathrm{rBC}$ values reached their maximums in the 1960s and 1970s.

Concentrations and relative change to levels of the preindustrial era (here defined as 1825-1850) for given time periods are summarized in Table 1. For the period of 18251850 , medians ( \pm standard deviation, SD) of rBC concentrations were $4.3 \pm 1.5$ in summer and $2.0 \pm 0.9 \mu \mathrm{g} \mathrm{L}^{-1}$ in winter. The rBC concentrations increased $\sim 1.5$-fold in 19001950. Meanwhile, the slight increase in winter $\mathrm{rBC}$ values in 1900-1920 with respect to summer rBC values is not well understood. Although speculative, it may reflect increased winter $\mathrm{BC}$ inputs transporting through the free troposphere (FT) from North America, where BC emissions markedly increased at the beginning of the 20th century (Lamarque et al., 2010; McConnell et al., 2007). Over the period of 19601980, rBC concentrations increased by a factor of 5.0 in summer and a factor of 3.3 in winter. The larger relative change in summer $\mathrm{rBC}$ than one of winter for the period suggests that $\mathrm{rBC}$ emissions in the summer source region increased more sharply for this time period. Notably, in addition to medians, the lower 10th percentiles of both summer and winter $\mathrm{rBC}$ records increased since the preindustrial era, highlighting that the rBC background level in the atmosphere at ELB was also significantly modified. Meanwhile, the upper 10 th percentiles ranged up to 75,35 and $56 \mu \mathrm{g} \mathrm{L}^{-1}$ for summer, winter and annual variability, respectively.

Of the EC records available in the western European mountain glaciers, only Col du Dôme (hereafter CDD; Legrand et al., 2007) and Colle Gnifetti (hereafter CG;
Thevenon et al., 2009) summer records provide EC records for the recent time (until $\sim 1990$ and 1980, respectively), whereas the Fiescherhorn (hereafter FH; Jenk et al., 2006) record is available until 1940 only. Both summer records at CDD and CG show somewhat comparable preindustrial EC levels $\left(\sim 2 \mu \mathrm{g} \mathrm{L}^{-1}\right.$ for CDD and $\sim 7 \mu \mathrm{g} \mathrm{L}^{-1}$ for $\mathrm{CG}$ in the mid-1800s) to the ELB rBC $\left(4.3 \pm 1.5 \mu \mathrm{g} \mathrm{L}^{-1}\right.$ in $\left.1825-1850\right)$ and substantially increased EC concentrations for the period 1950-1980 since the mid 20th century, similar to the ELB rBC. This suggests that EC emissions show a common trend at the European scale, and that such a trend has been recorded in the different European high-altitude ice cores from CDD, $\mathrm{CG}$, and ELB. Some differences, such as the peak time period and an increase/decrease rate between records that may reflect sub-regional (e.g., western Europe vs. eastern Europe) emission changes, may also be noteworthy. However, direct comparison of the ELB rBC with the western European ice core records should be made with caution owing to both (i) different analytical methods applied for the ice cores (e.g., ELB rBC: APEX-Q/SP2, CDD EC: thermal-optical method with the EUSAAR2 protocol, and CG EC: thermal method; Lim et al., 2014) and (ii) lower data resolution, particularly for the CDD core (a few data points for a decadal EC concentration). We thus focus on evaluating the ELB $\mathrm{rBC}$ record in Sect. 3.5 by comparing with the simulated atmospheric load of BC particles that were transported from source regions to Mt. Elbrus.

\subsection{Past variability in $\mathrm{rBC}$ size distributions}

The first record of temporal and seasonal changes in the $\mathrm{rBC}$ size distribution was extracted from the ELB ice core. The mass equivalent diameter of $\mathrm{rBC}$ particles $\left(D_{\mathrm{rBC}}\right)$ was $\log$ normally distributed. The mode of $\mathrm{rBC}$ mass size distributions (mass mode diameter, MMD) was determined for both summer and winter layers by fitting a log-normal curve to the measured distribution (e.g., Fig. S2). This approach provides reliable results of representative $\mathrm{rBC}$ sizes in seasonal ice layers as the determined MMDs fall into the measured size range $(\sim 70-620 \mathrm{~nm})$. 


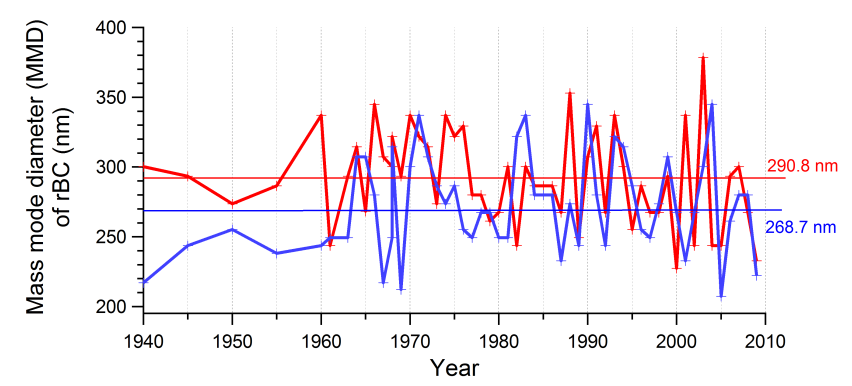

Figure 5. Time series of the mass mode diameter (MMD) of seasonal $\mathrm{rBC}$ size distributions for the period 1940-2009. The MMD was obtained by fitting a log-normal curve to the measured distribution. Horizontal lines stand for the geometric means for summer (red) and winter (blue).

Figure 5 shows time series of $\mathrm{rBC}$ MMD for the period of 1940 to 2009. The upper and lower limits of the periods selected for retrieving $\mathrm{rBC}$ MMD were chosen so as a large number of $\mathrm{rBC}$ particles in the seasonal ice layer would be available and would allow one to secure a reliable size distribution of the ice layer. Faster melting of snow layers of years 2010-2013 and thinner ice layers below the layer of year 1940 did not allow one to record sufficient numbers of $\mathrm{rBC}$ particles, and thus robust $\mathrm{rBC}$ size distributions could not be retrieved. For the considered time period, rBC MMD of both summer and winter layers varied, ranging from 207.3 to $378.3 \mathrm{~nm}$ with a geometric mean of $279.4 \pm 1.1 \mathrm{~nm}$. No statistically significant temporal change in $\mathrm{rBC}$ MMD was identified over the 1940-2009 period.

Notably, rBC particles measured in this study show the MMD shifted to larger sizes than those measured in the atmosphere over Europe (MMD of 130-260 nm; Dahlkotter et al., 2014; Laborde et al., 2013; Liu et al., 2010; McMeeking et al., 2010; Reddington et al., 2013), even larger than the atmospheric $\mathrm{rBC}$ diameter measured at a high Alpine site, Jungfraujoch (JFJ) in Switzerland (MMD of 220-240 nm; Liu et al., 2010). The shift in rBC sizes induced by dry deposition should be negligible, as a quite high (100-200 $\mathrm{mm} \mathrm{month}^{-1}$ ) and fairly constant precipitation rate throughout the year near the drilling site (e.g., 52 and $48 \%$ of annual precipitation observed in summer and winter, respectively, at Klukhorskiy Pereval station; see Sect. 2.3) suggests that wet deposition can be the dominant aerosol removal pathway at this site. Similarly, significant snowmelt was not observed in the ELB summer ice layers. Although there is a lack of studies about the impact of snow melting on $\mathrm{rBC}$ size distribution, such processes would not be expected at the ELB drilling site. Rather, the different $\mathrm{rBC}$ size distributions of the ice core from those in the atmosphere are likely associated with removal process of $\mathrm{rBC}$ particles during precipitation. A recent study using the SP2 technique showed the $\mathrm{rBC}$ size distribution in rainwater shifted to larger sizes $(\mathrm{MMD}=\sim 200 \mathrm{~nm})$ than that in air $(\mathrm{MMD}=\sim 150 \mathrm{~nm})$ in
Tokyo, indicating that large $\mathrm{rBC}$ particles were more efficiently removed by precipitation (Mori et al., 2016). The preferential wet removal of larger rBC particles (Mori et al., 2016; Moteki et al., 2012) could reasonably explain the larger MMD of rBC particles observed in the ice core than atmospheric rBC aerosols (Schwarz et al., 2013).

The difference in seasonal $\mathrm{rBC}$ size distributions was statistically significant $(p<0.01)$. In summer, the MMD varied, ranging from 227.4 to $378.3 \mathrm{~nm}$ with a geometric mean of $290.8 \pm 1.1 \mathrm{~nm}$ (Fig. 5, red curve). In winter, the MMD varied, ranging from 207.3 to $344.9 \mathrm{~nm}$ with a geometric mean of $268.7 \pm 1.1 \mathrm{~nm}$ (Fig. 5, blue curve). The rBC MMD of summer ice layers tended to be slightly larger than that of winter layers. Despite little observational evidence, we hypothesize that larger $\mathrm{rBC}$ sizes in summer may reflect advection of $\mathrm{rBC}$ aerosols transported from the PBL by thermally driven convection, while in winter aerosols transported in the FT could be smaller due to longer residence time in the atmosphere and, accordingly, more chances for larger aerosols to be removed by precipitation prior to reaching the ELB site. Our hypothesis seems to be reasonable, being consistent with the findings of in situ aerosol measurements at high-altitude sites in Europe. Liu et al. (2010) found that rBC aerosols at JFJ were slightly larger when the site was influenced by valley sources, anthropogenic pollutants from lower altitudes. Submicron aerosol size distributions were also overall shifted to larger sizes in summer (50 to $150 \mathrm{~nm}$ ) than in winter (below $50 \mathrm{~nm}$ ) at European mountain stations with an altitude of $\sim 1000-3000$ m a.s.l. (Asmi et al., 2011). The authors in the latter explained this feature by relatively polluted air masses from the PBL during daytime in summer but more influence of the FT air masses in winter. Similar to the clear seasonal cycle in $\mathrm{rBC}$ mass concentration, the clear seasonal $\mathrm{rBC}$ size distributions of the ELB ice core point to seasonal differences in the origins of air masses reaching the ELB drilling site: PBL air with less chance of aerosol wet removal in summer and FT air in winter.

In addition, the larger $\mathrm{rBC}$ MMD in summer layers can be associated with specific summer sources of atmospheric rBC particles, such as forest fires and/or agricultural fires. Particularly, forest fires in southern Europe and agricultural fires in eastern Europe may well contribute to summer aerosol loading in Europe (Bovchaliuk et al., 2013; van der Werf et al., 2010; Yoon et al., 2011). Previous SP2 studies have reported the larger size of $\mathrm{rBC}$ aerosols for biomass burning plumes, e.g., MMD of $\sim 200 \mathrm{~nm}$ (Kondo et al., 2011b; Schwarz et al., 2008; Taylor et al., 2014), compared to rBC sizes for urban plumes. In the ELB ice core, we observed a maximum $\mathrm{rBC}$ MMD of $378.3 \mathrm{~nm}$, with a maximum $\mathrm{rBC}$ mass concentration of $222.2 \mu \mathrm{g} \mathrm{L}^{-1}$ in the late summer snow layer of year 2003, when extreme forest fire events occurred over the Iberian Peninsula and the Mediterranean coast (Barbosa et al., 2004; Hodzic et al., 2006), resulting from a recordbreaking heatwave in Europe (Luterbacher et al., 2004; Schar et al., 2004). Both forward and backward air mass trajectories 

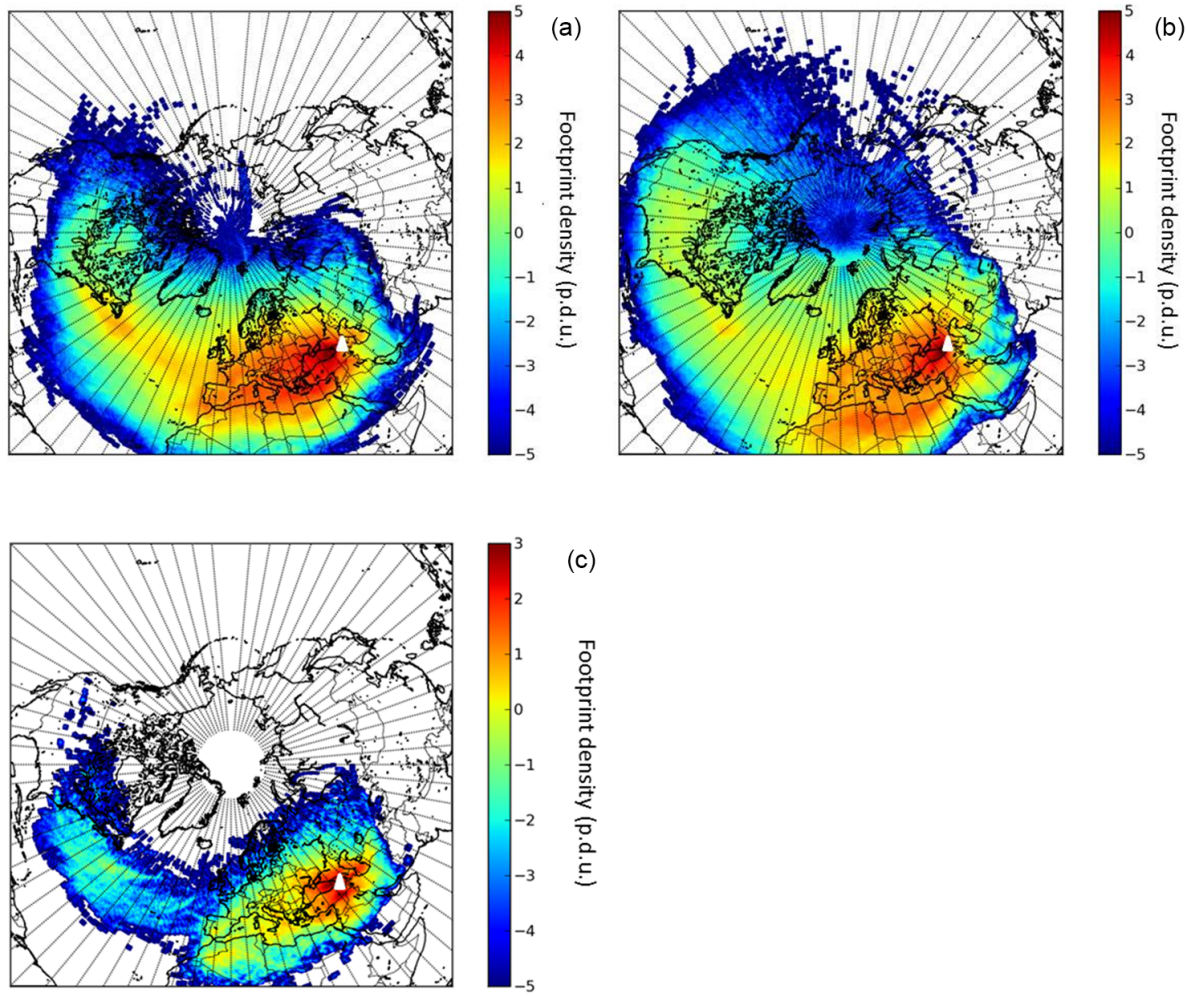

(c)

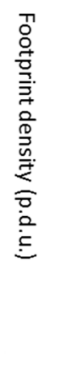

Figure 6. Air mass footprint area for (a) June to August (JJA) and (b) December to February (DJF) in the atmospheric column and (c) JJA in the lowest $2 \mathrm{~km}$ in the atmosphere. The color bar on the left indicates footprint density with a process defined unit (p.d.u.). The location of the ELB site is marked by a white triangle. JJA and DJF correspond to summer and winter of the ELB ice core depth, respectively.

calculated from the HYSPLIT model support the ELB site being potentially influenced by the intense forest fires that occurred in the southern part of Europe in mid-August 2003 (Fig. S3), when the top altitude of the PBL was estimated to be $\sim 4.5 \mathrm{~km}$ high (Hodzic et al., 2006). Although speculative, this snow layer of year 2003 that peaked with $\mathrm{rBC}$ concentration and was enriched with larger-sized rBC particles indicates that the potential contribution of biomass burning aerosols transported westerly to the ELB site. This 2003 summer snow layer experienced some melting (Kozachek et al., 2016), but we can rule out that such melting was driving the unusual MMD signal described above, and other snow layers with melting events did not show any anomalies of rBC MMD toward larger values. The $\mathrm{rBC}$ size distributions preserved in the ELB core could be discussed as an influence of seasonal vertical transport versus emission sources of $\mathrm{rBC}$ aerosols and their wet removal properties. This $\mathrm{rBC}$ size information has the potential to provide important implications, particularly for the determination of snow-melting potential by rBC particles in snow (Flanner et al., 2007; Schwarz et al., 2013). Comparison of rBC size with wellestablished biomass burning proxies would be required to better characterize the dependency of $\mathrm{rBC}$ sizes with past fire activities.

\subsection{Potential emission source regions}

Figure 6 illustrates potential source regions of BC aerosols reaching the ELB site. The model results show that, relative to the footprints in JJA, footprints in DJF were more spread out of the European continent and extended further over the Pacific (Fig. 6a and b). The relative contributions of each regional footprint density over the total density are summarized in Fig. 7. Most aerosols reaching the ELB site are transported from the European continent (WEU + CEU + EEU), accounting for 71.0 and $55.6 \%$ in JJA and DJF, respectively, and particularly from the eastern part of Europe (CEU + EEU), accounting for 59.0 and $47.0 \%$ in JJA and DJF, respectively. The EEU region brings the greatest contribution with fairly consistent features for both seasons, accounting for 35.6 and $30.9 \%$ in JJA and DJF, respectively. A stronger seasonality was found in the NAF region and the NAM region, where the footprint contribution was larger in DJF by 2 -fold. This seasonal variation is caused by longer particle trajectories promoted by a faster zonal flow in winter across the North Atlantic from west to east.

To investigate contributions of aerosols transporting from low altitudes which may reflect emissions at the surface more sensitively, we calculated the footprint density of particles positioned in the lowest $2 \mathrm{~km}$ layers in the atmosphere. Note 
(a)

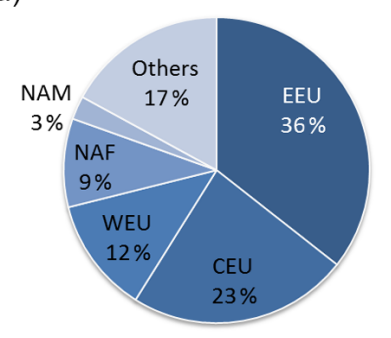

(b)

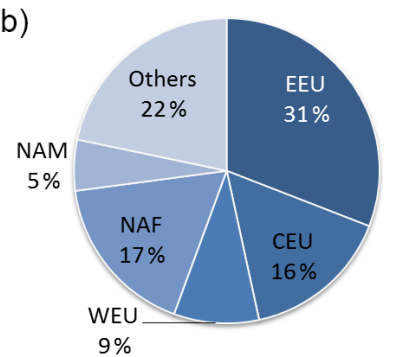

(c)

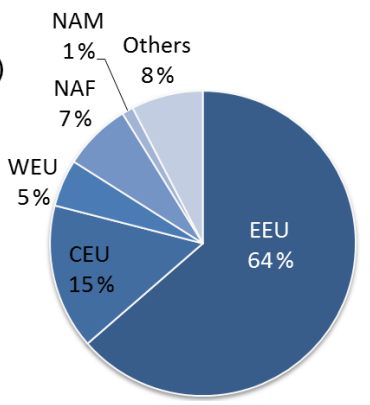

Figure 7. Contribution of each regional footprint density (\%) for (a) JJA and (b) DJF in the atmospheric column and (c) JJA in the lowest $2 \mathrm{~km}$ in the atmosphere. The footprint density of each region is divided by the footprint density of the entire footprint area $(\mathrm{EEU}+\mathrm{CEU}+\mathrm{WEU}+\mathrm{NAF}+\mathrm{NAM}+$ Others $)$ and then described in percentage. Information for each region is found in Sect. 2.4.

that we arbitrarily selected this vertical height of the atmosphere $(2 \mathrm{~km}$ layer) since particles positioned at the lower atmosphere (e.g., $\sim 1 \mathrm{~km}$ layer) were rarely observed in our simulations, and the PBL heights were often higher in European mountains up to $3 \mathrm{~km}$ (Matthias et al., 2004). The results for JJA show that unlike in the entire atmospheric column, the contribution of footprint density from the EEU region was almost doubled in the $2 \mathrm{~km}$ layer, accounting for $63.6 \%$ (Fig. 6c). In contrast, in DJF, the proportion of the EEU region was only $22 \%$ over the total footprint density in this fixed layer. We thus infer that large seasonal increases observed during summertime in the $\mathrm{rBC}$ mass concentration are likely driven by deposition of $\mathrm{rBC}$ aerosols transported from the eastern part of Europe and mostly originating from lower altitudes.
Therefore, these FLEXPART results confirm that $\mathrm{rBC}$ deposition to Mt. Elbrus is most likely dominated by transport of $\mathrm{BC}$ emissions from the European continent, with the strongest BC inputs from the eastern part of Europe, particularly in summer.

\subsection{New constraints on European BC emissions}

Refractory BC concentrations of the ELB ice core increased rapidly from the 1950s to the 1980s (Fig. 4 in Sect. 3.2), and such a trend record should primarily reflect changes in European BC emissions (Sect. 3.4). Here, we compare past emission $\mathrm{BC}$ inventories with the ELB ice core record to bring new constraints on past European BC emissions.

Figure 8 shows temporal changes in anthropogenic and biomass burning BC emissions for the period 1900-2008 estimated by ACCMIP and MACCity (Diehl et al., 2012; Granier et al., 2011; Lamarque et al., 2010; van der Werf et al., 2006). The overall emission trends (black lines) illustrate a decrease in anthropogenic emissions since 1900 (Fig. 8a) and a high variability of biomass burning emissions over the whole period (Fig. 8b). For anthropogenic emissions, the largest $\mathrm{BC}$ emissions in the EEU and CEU regions occurred in 1980, followed by decreasing trends. WEU had the strongest BC emissions lasting until 1960, followed by a decrease in BC emissions lasting to the present day. In 2008, anthropogenic BC emissions in the EEU, CEU and WEU regions are comparable, with an order of $0.2 \mathrm{Tg} \mathrm{yr}^{-1}$.

To investigate factors controlling long-term $\mathrm{rBC}$ trends preserved in the ELB ice core, the temporal evolution of measured ice core $\mathrm{rBC}$ particles can be directly compared with that of atmospheric BC load at the ELB site, at least in a relative manner. This comparison is provided in Fig. 9, in which the ice core record is averaged along a decadal scale to be comparable with the historic $\mathrm{BC}$ emission data available on the decadal scale only (Lamarque et al., 2010). Specifically, we coupled the $\mathrm{BC}$ emission intensities in each region and their relative contribution to the entire footprint area of the ELB site (Fig. $8 \mathrm{c}$ and d). The decadal BC emission burden in each region (Fig. 8a and b) is therefore multiplied by the contribution of footprint density (Fig. 7). The assumption behind this comparison is that (i) the atmospheric circulation and transport patterns do not change with time and that (ii) the mechanisms for BC depositing on snow remained constant. Hence, the proportionality between $\mathrm{BC}$ mass concentration in snow and atmospheric $\mathrm{BC}$ load has not varied with time.

For summertime (JJA case, Fig. 9a), optimal agreement in the trend pattern is observed between the ice core $\mathrm{rBC}$ and the atmospheric $\mathrm{BC}$ estimated in the lower $2 \mathrm{~km}$ layer with an increase at the onset of the 20th century and a subsequent decrease since $\sim 1980$ ("best scenario"). Specifically, a substantial increase in atmospheric BC load is observed for the period 1910-1970, similar to the ELB rBC ice core record, only when the atmospheric BC considers BC particles transported in the lowest $2 \mathrm{~km}$ layer of the atmosphere. 
(a)

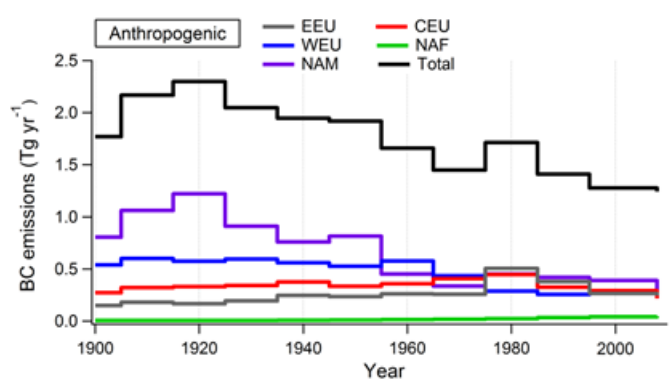

(c)

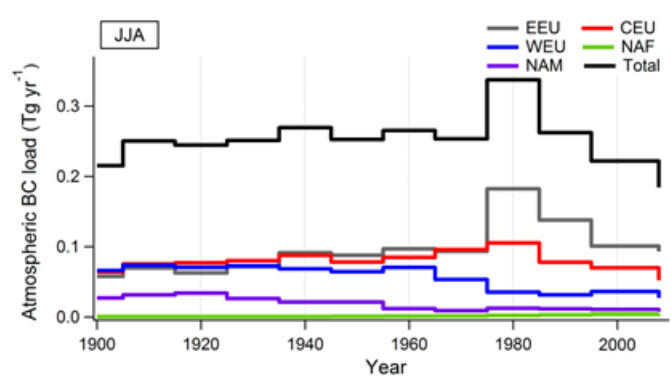

(b)

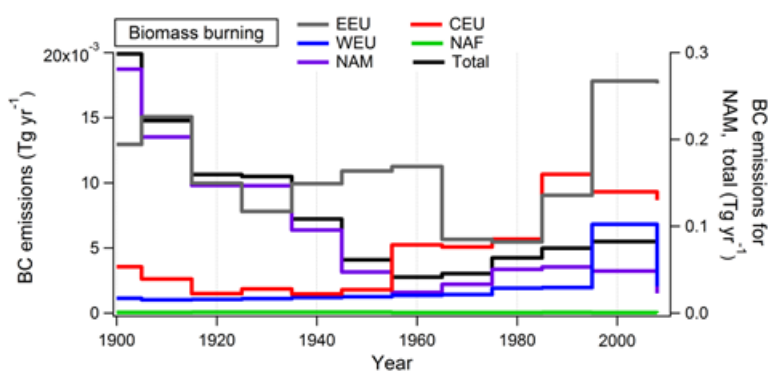

(d)

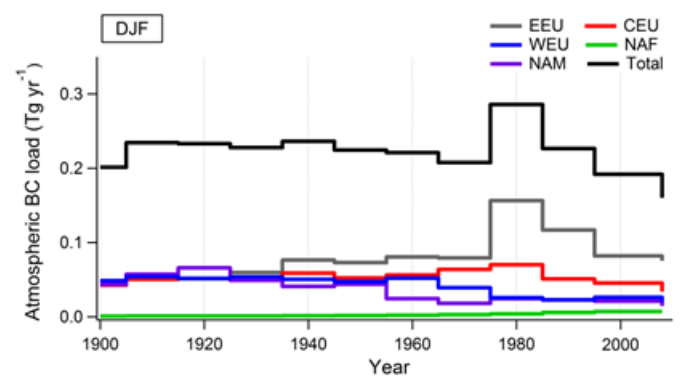

Figure 8. Historic regional BC emissions and atmospheric BC load at ELB for the period 1900-2008. In (a) and (b), anthropogenic and biomass burning (forest fires and savanna burning) BC emissions estimated by ACCMIP and MACCity (Diehl et al., 2012; Granier et al., 2011; Lamarque et al., 2010; van der Werf et al., 2006). In (c) and (d), atmospheric BC load ( $\mathrm{Tg} \mathrm{yr}^{-1}$ ) is calculated by multiplying decadal-scale BC emissions in each region (a, b) by their relative contribution to the entire footprint area of the ELB site (Fig. 7). In (c), both anthropogenic and biomass burning emissions are used for the reconstruction for JJA, as this type of biomass burning (forest fires and savanna burning) is the most frequent in summer, and in (d), only anthropogenic emissions are used for DJF.

On the other hand, the estimation derived from the entire atmospheric column does exhibit a different pattern. This comparison indicates that changes primarily in European anthropogenic BC emissions (e.g., industry, traffic and residential combustions), particularly ones of the eastern part of Europe, are consequently reflected in the ELB ice core $\mathrm{rBC}$ variability over the last century.

For wintertime (DJF case, Fig. 9b), the ice core rBC variability before 1980 can be explained by the atmospheric BC load (anthropogenic only) in the entire atmospheric column, but without North American (NAM) contribution. With the NAM contribution included in the simulation, the atmospheric BC is overestimated before 1980, resulting in a flat or slightly downward trend for the period 1910-1970, unlike the ice core $\mathrm{rBC}$ trend. However, the good agreement between long-term $\mathrm{rBC}$ changes in Greenland ice core and modeled $\mathrm{BC}$ deposition in Greenland using a chemistry-climate model with an input of the ACCMIP BC inventory confirms that BC emission estimates for NAM from the ACCMIP inventory correctly quantify anthropogenic $\mathrm{BC}$ emissions in North America (Lamarque et al., 2010). Consequently, the observed overestimation of the NAM contribution for winter at the ELB site (Fig. 9b) is likely due to an overestimation of the NAM footprint density in the statistical process applied to FLEXPART simulation data. The stronger BC inputs from NAM might have contributed to the increased winter $\mathrm{rBC}$ concentrations of the ELB ice core at the beginning of the 20th century, although it was not shown in our simulations. Finally, the estimated BC without a NAM contribution is defined as the "best scenario" for wintertime.

Despite the similar features between the ice core rBC record and the best scenario for the atmospheric load which support the anthropogenic BC increase in the 20th century being reflected in the ELB record, the BC maximum time period is not in total agreement (Fig. 9a and b). Unlike the ice core $\mathrm{rBC}$ that already largely increased in 1960 and peaked in 1970 for both summer and winter, the atmospheric BC load remarkably increases only in 1980. Substantial BC increase in ELB and western European (CDD and CG) ice cores since the mid-20th century reveals that $\mathrm{BC}$ emissions increased during that period at a wide regional European scale. In addition, the CDD record shows a large increase in sulfate concentration since the mid-20th century lasting until $\sim 1980$ (Preunkert et al., 2001; Preunkert and Legrand, 2013). Knowing that sulfate and $\mathrm{BC}$ are often co-emitted in anthropogenic emission sources, e.g., in industrial sectors, one can expect a large increase in European BC emissions since the mid-20th century, as suggested by the ELB ice core $\mathrm{rBC}$ record. The re- 

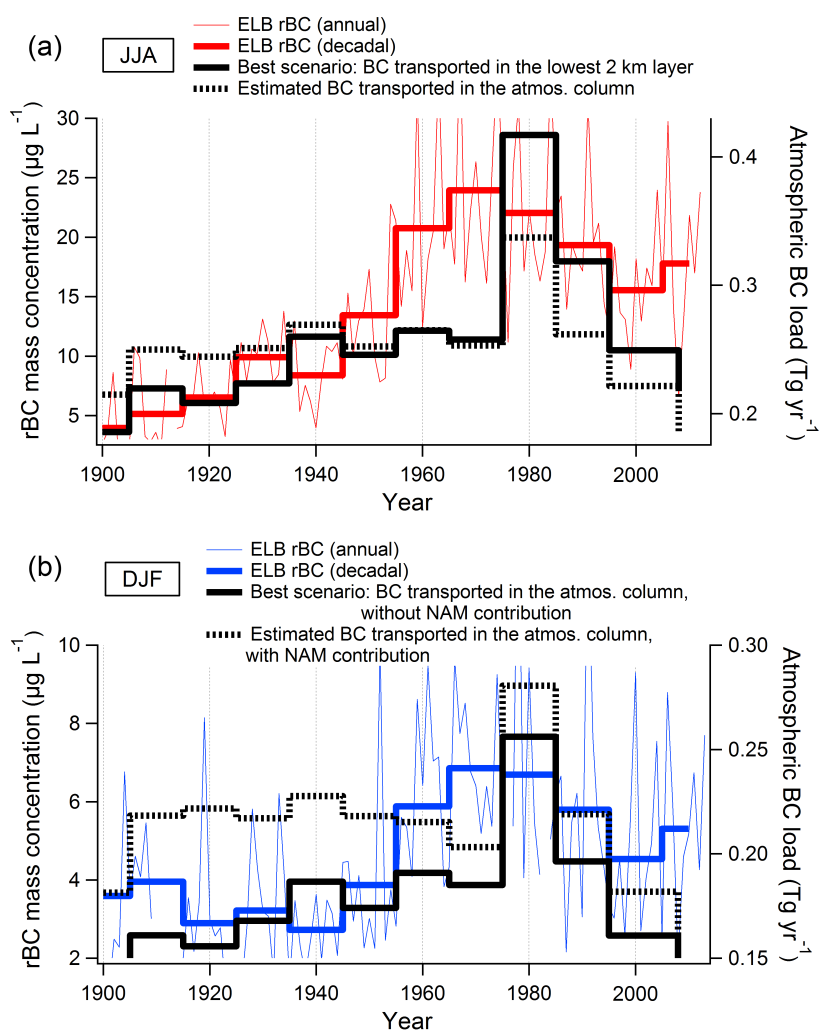

Figure 9. Comparison in temporal evolution between the $\mathrm{rBC}$ mass concentration of the ELB ice core and the estimates of atmospheric BC load at the ELB site, on a decadal scale. (a) JJA and (b) DJF. Best scenarios for atmospheric BC load are shown in black thick lines. In (b), NAM stands for North America.

liability of historic emission inventories for $\mathrm{BC}$ is reported to be lower than that for $\mathrm{SO}_{2}, \mathrm{CO}$ and NOx emissions, particularly for the period prior to 2000 (Granier et al., 2011), which is due to the uncertainties in $\mathrm{BC}$ emission factors for coal, gasoline and diesel fuels in various sectors (differ by a factor of 10 or more in the literature) and activity data (Granier et al., 2011; Vignati et al., 2010). Thus, the lack of a substantial increase in the atmospheric BC load for the period 1960s-1970s could be associated primarily with underestimated European anthropogenic BC emissions for this period (Fig. 8c and d).

Moreover, the ice core $\mathrm{rBC}$ record and the atmospheric BC load do not exhibit similar patterns after 1980. Decreasing rates of the ice core $\mathrm{rBC}$ are much slower after 1980 onward for both seasons than the atmospheric BC load (Fig. 9a and $b$ ). Furthermore, the summer $\mathrm{rBC}$ trend of the ELB ice core even increased since 2000, although such a trend cannot be reported conclusively for winter layers (Fig. 4). The recent economic growth in eastern, and some parts of central, European countries (World Bank Group, 2016) can contribute to the enhancement in the release of BC and co-emitted pollutants. Some eastern European countries have kept increasing their sulfur emissions mainly from heat production and public electricity from 2000 onward (Vestreng et al., 2007). Thus, the increase in rBC deposition at the Elbrus site, mostly identified in summer, was probably related to enhanced emissions from anthropogenic sources located in eastern and central Europe. On the other hand, many eastern European countries, such as Ukraine and the European part Russia which are geographically close to Mt. Elbrus, are the countries with the greatest land use for agriculture in Europe (Rabbinge and van Diepen, 2000), and thus emissions of smoke aerosols from their agricultural waste burning are expected to be significant in summertime (Barnaba et al., 2011; Bovchaliuk et al., 2013; Stohl et al., 2007). Large emissions of smoke aerosols over eastern Europe from summer forest/agricultural fires have been recently reported (Barnaba et al., 2011; Bovchaliuk et al., 2013; Sciare et al., 2008; Yoon et al., 2011; Zhou et al., 2012) and burned area from the Global Fire Emissions Database (GFED; Giglio et al., 2010) increased over eastern Europe for the period 2004-2008 (Yoon et al., 2014). These emissions of smoke aerosols in the eastern part of Europe may have contributed to the observed summer BC increase in the ELB ice cores. Thus, the recent trend of the ELB ice core $\mathrm{rBC}$ turning upward probably indicates changes in both anthropogenic emissions and summer forest/peat fires over the eastern part of Europe in the 2000s, which is not well reflected in the inventories.

Given the large existing uncertainties in historic $\mathrm{BC}$ emission inventories available to date, our $\mathrm{rBC}$ record reconstructed from the high-altitude Caucasus ice cores should be useful in better constraining European BC emissions. Specifically, our study highlights the need to improve BC emission inventories from the eastern part of Europe since 1960. Reliability of western European BC emissions could be more specifically assessed by investigating high-resolution $\mathrm{BC}$ records extracted from western European ice cores that would be more representative of western European emissions.

\section{Conclusions}

A high-resolution $\mathrm{rBC}$ record reconstructed from ice cores drilled from a high-altitude eastern European site in Mt. Elbrus (ELB), Caucasus, reported for the first time the longterm evolutions of $\mathrm{rBC}$ mass concentrations and size distributions in the European outflows over the past 189 years, i.e., between year 1825 and year 2013. The $\mathrm{rBC}$ record at ELB was largely impacted by $\mathrm{rBC}$ emissions located in the eastern part of Europe. A large temporal variability in $\mathrm{rBC}$ mass concentration was observed at both seasonal and annual timescales. This record was also unique in documenting long-term variability of $\mathrm{BC}$ in this region of Europe.

In the first half of the 20th century, $\mathrm{rBC}$ concentrations increased 1.5-fold over their level in the preindustrial era (before 1850). The summer (winter) $\mathrm{rBC}$ concentrations increased 5-fold (3.3-fold) in 1960-1980, followed by a de- 
crease until $\sim 2000$ and a slight increase again since $\sim 2000$. Consistent increase in background levels since the beginning of 20th century highlights that the rBC background level in the atmosphere at ELB was also significantly altered. We have also investigated the potential of size distributions of rBC particles in the ice cores as a new proxy to bring additional information on $\mathrm{rBC}$ removal processes, seasonal transport patterns, and emission sources.

We simulated the atmospheric load of $\mathrm{BC}$ aerosols which were transported from the European continent, mainly the eastern part of Europe, by coupling transport simulations (FLEXPART) to 20th-century BC emission inventories (ACCMIP and MACCity). Similar features were observed between the ELB ice core $\mathrm{rBC}$ mass concentration record and the best scenario for the atmospheric BC load at the ELB site: a BC increase at the onset of the 20th century and a subsequent decrease since $\sim 1980$. This estimation evidently supports European anthropogenic activities resulting in the $\mathrm{BC}$ increase over Europe since $\sim 1900$, which was also seen in elemental carbon (EC) records of western European ice cores (Legrand et al., 2007; Thevenon et al., 2009). However, some disagreements were seen between the ELB ice core $\mathrm{rBC}$ and the best scenario for atmospheric BC load at ELB, e.g., (i) the lack of a strong increase in the best scenario for the period 1960s and 1970s, unlike the ice core record, (ii) the different decreasing rates after 1980 and (iii) the slightly increasing trend of the rBC ELB ice core summer record since 2000 that was not shown in the estimation. An explanation for such a discrepancy could be that rapid enhancement of BC emissions over Europe since 1960 and the recent BC changes in the eastern part of Europe may not be well accounted for in the emission inventories.

Most atmospheric BC measurements have focused on western and northern Europe (e.g., McMeeking et al., 2010; Reche et al., 2011; Reddington et al., 2013) despite growing evidence of strong aerosol emissions in the eastern part of Europe (Asmi et al., 2011; Barnaba et al., 2011; Bovchaliuk et al., 2013). It is thus critically important to deploy new studies (atmospheric monitoring and investigation of ice archives) with a more comprehensive European view, including both western and eastern areas. We suggest that century-long ice cores at multiple high-altitude European sites with homogeneous or well-cross-compared measurement techniques are needed to better constrain past BC emissions, infer efficiency of present $\mathrm{BC}$ emission regulation, and help establish future regulations on $\mathrm{BC}$ emissions.

\section{The Supplement related to this article is available online at doi:10.5194/acp-17-3489-2017-supplement.}

Competing interests. The authors declare that they have no conflict of interest.
Acknowledgements. This work was supported by the PEGASOS project funded by the European Commission under the Framework Programme 7 (FP7-ENV-2010-265148) and by the Russian Foundation for Basic Research (RFBR) grants 07-05-00410 and 09-05-10043. This work received funding from French ANR program RPD COCLICO (ANR-10-RPDOC-002-01) and the European Research Council under the European Community's Seventh Framework Program FP7/2007-2013 grant agreement no. 291062 (project ICE\&LASERS). Saehee Lim acknowledges the support of the Korean Ministry of Education and Science Technology through a government scholarship and of the Basic Science Research Program through the National Research Foundation of Korea (NRF) funded by the Ministry of Education (2015R1A6A3A01061393). Vladimir Mikhalenko and Stanislav Kutuzov acknowledge the support of the Russian Academy of Sciences (Department of Earth Sciences ONZ-12 project) and RFBR grant 14-05-00137. Grateful thanks to M. Zanatta for technical help in SP2 operation, S. Preunkert for technical help in ice core cutting, M. Legrand for helpful discussions, A. Berchet and J.-L. Bonne for help in FLEXPART simulations and N. Kehrwald for analytical help.

Edited by: C. Barbante

Reviewed by: two anonymous referees

\section{References}

Asmi, A., Wiedensohler, A., Laj, P., Fjaeraa, A.-M., Sellegri, K., Birmili, W., Weingartner, E., Baltensperger, U., Zdimal, V., Zikova, N., Putaud, J.-P., Marinoni, A., Tunved, P., Hansson, H.C., Fiebig, M., Kivekäs, N., Lihavainen, H., Asmi, E., Ulevicius, V., Aalto, P. P., Swietlicki, E., Kristensson, A., Mihalopoulos, N., Kalivitis, N., Kalapov, I., Kiss, G., de Leeuw, G., Henzing, B., Harrison, R. M., Beddows, D., O’Dowd, C., Jennings, S. G., Flentje, H., Weinhold, K., Meinhardt, F., Ries, L., and Kulmala, M.: Number size distributions and seasonality of submicron particles in Europe 2008-2009, Atmos. Chem. Phys., 11, 5505-5538, doi:10.5194/acp-11-5505-2011, 2011.

Barbosa, P., San-Miguel-Ayanz, J., Camia, A., Gimeno, M., Liberta, G., and Schmuck, G.: Assessment of fire damages in the EU Mediterranean Countries during the 2003 Forest Fire Campaign, Official Publication of the European Commission, Ispra, 2004.

Barnaba, F., Angelini, F., Curci, G., and Gobbi, G. P.: An important fingerprint of wildfires on the European aerosol load, Atmos. Chem. Phys., 11, 10487-10501, doi:10.5194/acp-1110487-2011, 2011.

Bisiaux, M. M., Edwards, R., McConnell, J. R., Curran, M. A. J., Van Ommen, T. D., Smith, A. M., Neumann, T. A., Pasteris, D. R., Penner, J. E., and Taylor, K.: Changes in black carbon deposition to Antarctica from two high-resolution ice core records, 1850-2000 AD, Atmos. Chem. Phys., 12, 4107-4115, doi:10.5194/acp-12-4107-2012, 2012a.

Bisiaux, M. M., Edwards, R., McConnell, J. R., Albert, M. R., Anschütz, H., Neumann, T. A., Isaksson, E., and Penner, J. E.: Variability of black carbon deposition to the East Antarctic Plateau, 1800-2000 AD, Atmos. Chem. Phys., 12, 3799-3808, doi:10.5194/acp-12-3799-2012, $2012 b$. 
Bond, T. C., Doherty, S. J., Fahey, D. W., Forster, P. M., Berntsen, T., DeAngelo, B. J., Flanner, M. G., Ghan, S., Karcher, B., Koch, D., Kinne, S., Kondo, Y., Quinn, P. K., Sarofim, M. C., Schultz, M. G., Schulz, M., Venkataraman, C., Zhang, H., Zhang, S., Bellouin, N., Guttikunda, S. K., Hopke, P. K., Jacobson, M. Z., Kaiser, J. W., Klimont, Z., Lohmann, U., Schwarz, J. P., Shindell, D., Storelvmo, T., Warren, S. G., and Zender, C. S.: Bounding the role of black carbon in the climate system: A scientific assessment, J. Geophys. Res.-Atmos., 118, 5380-5552, doi:10.1002/jgrd.50171, 2013.

Bovchaliuk, A., Milinevsky, G., Danylevsky, V., Goloub, P., Dubovik, O., Holdak, A., Ducos, F., and Sosonkin, M.: Variability of aerosol properties over Eastern Europe observed from ground and satellites in the period from 2003 to 2011, Atmos. Chem. Phys., 13, 6587-6602, doi:10.5194/acp-13-6587-2013, 2013.

Bukowiecki, N., Weingartner, E., Gysel, M., Collaud Coen, M., Zieger, P., Herrmann, E., Steinbacher, M., Gaggeler, H. W., and Baltensperger, U.: A Review of More Than 20 Years of Aerosol Observation at the High Altitude Research Station Jungfraujoch, Switzerland (3580 m a.s.1.), Aerosol Air Qual. Res., 16, 764-788, doi:10.4209/aaqr.2015.05.0305, 2016.

Collaud Coen, M., Weingartner, E., Nyeki, S., Cozic, J., Henning, S., Verheggen, B., Gehrig, R., and Baltensperger, U.: Long-term trend analysis of aerosol variables at the highalpine site Jungfraujoch, J. Geophys. Res., 112, D13213, doi:10.1029/2006JD007995, 2007.

Collaud Coen, M., Andrews, E., Asmi, A., Baltensperger, U., Bukowiecki, N., Day, D., Fiebig, M., Fjaeraa, A. M., Flentje, H., Hyvärinen, A., Jefferson, A., Jennings, S. G., Kouvarakis, G., Lihavainen, H., Lund Myhre, C., Malm, W. C., Mihapopoulos, N., Molenar, J. V., O’Dowd, C., Ogren, J. A., Schichtel, B. A., Sheridan, P., Virkkula, A., Weingartner, E., Weller, R., and Laj, P.: Aerosol decadal trends - Part 1: In-situ optical measurements at GAW and IMPROVE stations, Atmos. Chem. Phys., 13, 869894, doi:10.5194/acp-13-869-2013, 2013.

Dahlkötter, F., Gysel, M., Sauer, D., Minikin, A., Baumann, R., Seifert, P., Ansmann, A., Fromm, M., Voigt, C., and Weinzierl, B.: The Pagami Creek smoke plume after long-range transport to the upper troposphere over Europe - aerosol properties and black carbon mixing state, Atmos. Chem. Phys., 14, 6111-6137, doi:10.5194/acp-14-6111-2014, 2014.

Diehl, T., Heil, A., Chin, M., Pan, X., Streets, D., Schultz, M., and Kinne, S.: Anthropogenic, biomass burning, and volcanic emissions of black carbon, organic carbon, and $\mathrm{SO}_{2}$ from 1980 to 2010 for hindcast model experiments, Atmos. Chem. Phys. Discuss., 12, 24895-24954, doi:10.5194/acpd-12-24895-2012, 2012.

Fagerli, H., Legrand, M., Preunkert, S., Vestreng, V., Simpson, D., and Cerqueira, M.: Modeling historical long-term trends of sulfate, ammonium, and elemental carbon over Europe: A comparison with ice core records in the Alps, J. Geophys. Res., 112, D23S13, doi:10.1029/2006JD008044, 2007.

Flanner, M. G., Zender, C. S., Randerson, J. T., and Rasch, P. J.: Present-day climate forcing and response from black carbon in snow, J. Geophys. Res., 112, D11202, doi:10.1029/2006jd008003, 2007.

Forster, C., Stohl, A., and Seibert, P.: Parameterization of Convective Transport in a Lagrangian Particle Dispersion Model and Its Evaluation, J. Appl. Meteorol. Clim., 46, 403-422, doi:10.1175/JAM2470.1, 2007.

Giglio, L., Randerson, J. T., van der Werf, G. R., Kasibhatla, P. S., Collatz, G. J., Morton, D. C., and DeFries, R. S.: Assessing variability and long-term trends in burned area by merging multiple satellite fire products, Biogeosciences, 7, 1171-1186, doi:10.5194/bg-7-1171-2010, 2010.

Ginot, P., Dumont, M., Lim, S., Patris, N., Taupin, J.-D., Wagnon, P., Gilbert, A., Arnaud, Y., Marinoni, A., Bonasoni, P., and Laj, P.: A 10 year record of black carbon and dust from a Mera Peak ice core (Nepal): variability and potential impact on melting of Himalayan glaciers, The Cryosphere, 8, 1479-1496, doi:10.5194/tc-8-1479-2014, 2014.

Granier, C., Bessagnet, B., Bond, T. C., D’Angiola, A., Denier van der Gon, H., Frost, G. J., Heil, A., Kaiser, J. W., Kinne, S., Klimont, Z., Kloster, S., Lamarque, J.-F., Liousse, C., Masui, T., Meleux, F., Mieville, A., Ohara, T., Raut, J.-C., Riahi, K., Schultz, M. G., Smith, S. J., Thompson, A., Aardenne, J., Werf, G. R., and Vuuren, D. P.: Evolution of anthropogenic and biomass burning emissions of air pollutants at global and regional scales during the 1980-2010 period, Climate Change, 109, 163-190, doi:10.1007/s10584-011-0154-1, 2011.

Hansen, J. and Nazarenko, L.: Soot climate forcing via snow and ice albedos, P. Natl. Acad. Sci. USA, 101, 423-428, doi:10.1073/pnas.2237157100, 2004.

Hodzic, A., Vautard, R., Chepfer, H., Goloub, P., Menut, L., Chazette, P., Deuzé, J. L., Apituley, A., and Couvert, P.: Evolution of aerosol optical thickness over Europe during the August 2003 heat wave as seen from CHIMERE model simulations and POLDER data, Atmos. Chem. Phys., 6, 1853-1864, doi:10.5194/acp-6-1853-2006, 2006.

Jenk, T. M., Szidat, S., Schwikowski, M., Gäggeler, H. W., Brütsch, S., Wacker, L., Synal, H.-A., and Saurer, M.: Radiocarbon analysis in an Alpine ice core: record of anthropogenic and biogenic contributions to carbonaceous aerosols in the past (1650-1940), Atmos. Chem. Phys., 6, 5381-5390, doi:10.5194/acp-6-53812006, 2006.

Jenkins, M., Kaspari, S., Kang, S., Grigholm, B., and Mayewski, P. A.: Black carbon concentrations from a Tibetan Plateau ice core spanning 1843-1982: recent increases due to emissions and glacier melt, The Cryosphere Discuss., 7, 4855-4880, doi:10.5194/tcd-7-4855-2013, 2013.

Kaspari, S., Painter, T. H., Gysel, M., Skiles, S. M., and Schwikowski, M.: Seasonal and elevational variations of black carbon and dust in snow and ice in the Solu-Khumbu, Nepal and estimated radiative forcings, Atmos. Chem. Phys., 14, 80898103, doi:10.5194/acp-14-8089-2014, 2014.

Kaspari, S. D., Schwikowski, M., Gysel, M., Flanner, M. G., Kang, S., Hou, S., and Mayewski, P. A.: Recent increase in black carbon concentrations from a Mt. Everest ice core spanning 1860-2000 AD, Geophys. Res. Lett., 38, L04703, doi:10.1029/2010g1046096, 2011.

Kondo, Y., Sahu, L., Moteki, N., Khan, F., Takegawa, N., Liu, X., Koike, M., and Miyakawa, T.: Consistency and Traceability of Black Carbon Measurements Made by Laser-Induced Incandescence, Thermal-Optical Transmittance, and Filter-Based Photo-Absorption Techniques, Aerosol Sci. Technol., 45, 295312, doi:10.1080/02786826.2010.533215, 2011a. 
Kondo, Y., Matsui, H., Moteki, N., Sahu, L., Takegawa, N., Kajino, M., Zhao, Y., Cubison, M. J., Jimenez, J. L., Vay, S., Diskin, G. S., Anderson, B., Wisthaler, A., Mikoviny, T., Fuelberg, H. E., Blake, D. R., Huey, G., Weinheimer, A. J., Knapp, D. J., and Brune, W. H.: Emissions of black carbon, organic, and inorganic aerosols from biomass burning in North America and Asia in 2008, J. Geophys. Res., 116, D08204, doi:10.1029/2010JD015152, 2011b.

Kozachek, A., Mikhalenko, V., Masson-Delmotte, V., Ekaykin, A., Ginot, P., Kutuzov, S., Legrand, M., Lipenkov, V., and Preunkert, S.: Large-scale drivers of Caucasus climate variability in meteorological records and Mt Elbrus ice cores, Clim. Past Discuss., doi:10.5194/cp-2016-62, in review, 2016.

Laborde, M., Schnaiter, M., Linke, C., Saathoff, H., Naumann, K.H., Möhler, O., Berlenz, S., Wagner, U., Taylor, J. W., Liu, D., Flynn, M., Allan, J. D., Coe, H., Heimerl, K., Dahlkötter, F., Weinzierl, B., Wollny, A. G., Zanatta, M., Cozic, J., Laj, P., Hitzenberger, R., Schwarz, J. P., and Gysel, M.: Single Particle Soot Photometer intercomparison at the AIDA chamber, Atmos. Meas. Tech., 5, 3077-3097, doi:10.5194/amt-5-3077-2012, 2012.

Laborde, M., Crippa, M., Tritscher, T., Jurányi, Z., Decarlo, P. F., Temime-Roussel, B., Marchand, N., Eckhardt, S., Stohl, A., Baltensperger, U., Prévôt, A. S. H., Weingartner, E., and Gysel, M.: Black carbon physical properties and mixing state in the European megacity Paris, Atmos. Chem. Phys., 13, 5831-5856, doi:10.5194/acp-13-5831-2013, 2013.

Lamarque, J.-F., Bond, T. C., Eyring, V., Granier, C., Heil, A., Klimont, Z., Lee, D., Liousse, C., Mieville, A., Owen, B., Schultz, M. G., Shindell, D., Smith, S. J., Stehfest, E., Van Aardenne, J., Cooper, O. R., Kainuma, M., Mahowald, N., McConnell, J. R., Naik, V., Riahi, K., and van Vuuren, D. P.: Historical (1850-2000) gridded anthropogenic and biomass burning emissions of reactive gases and aerosols: methodology and application, Atmos. Chem. Phys., 10, 7017-7039, doi:10.5194/acp10-7017-2010, 2010.

Legrand, M., Preunkert, S., Schock, M., Cerqueira, M., KasperGiebl, A., Afonso, J., Pio, C., Gelencser, A., and DombrowskiEtchevers, I.: Major 20th century changes of carbonaceous aerosol components (EC, WinOC, DOC, HULIS, carboxylic acids, and cellulose) derived from Alpine ice cores, J. Geophys. Res., 112, D23S11, doi:10.1029/2006jd008080, 2007.

Legrand, M., Preunkert, S., May, B., Guilhermet, J., Hoffman, H., and Wagenbach, D.: Major 20th century changes of the content and chemical speciation of organic carbon archived in Alpine ice cores: Implications for the long-term change of organic aerosol over Europe, J. Geophys. Res.-Atmos., 118, 3879-3890, doi:10.1002/jgrd.50202, 2013.

Lim, S., Faïn, X., Zanatta, M., Cozic, J., Jaffrezo, J.-L., Ginot, P., and Laj, P.: Refractory black carbon mass concentrations in snow and ice: method evaluation and inter-comparison with elemental carbon measurement, Atmos. Meas. Tech., 7, 3307-3324, doi:10.5194/amt-7-3307-2014, 2014.

Liu, D., Flynn, M., Gysel, M., Targino, A., Crawford, I., Bower, K., Choularton, T., Jurányi, Z., Steinbacher, M., Hüglin, C., Curtius, J., Kampus, M., Petzold, A., Weingartner, E., Baltensperger, U., and Coe, H.: Single particle characterization of black carbon aerosols at a tropospheric alpine site in Switzerland, At- mos. Chem. Phys., 10, 7389-7407, doi:10.5194/acp-10-73892010, 2010.

Lugauer, M., Baltensperger, U., Furger, M., Gaggeler, H. W., Jost, D. T., Schwikowski, M., and Wanner, H.: Aerosol transport to the high Alpine sites Jungfraujoch (3454 ma.s.1.) and Colle Gnifetti (4452 m,a.s.1.), Tellus B, 50, 76-92, doi:10.3402/tellusb.v50i1.16026, 1998.

Luterbacher, J., Dietrich, D., Xoplaki, E., Grosjean, M., and Wanner, H.: European seasonal and annual temperature variability, trends, and extremes since 1500, Science, 303, 1499-503, doi:10.1126/science.1093877, 2004.

Matthias, V. and Bosenberg, J.: Aerosol climatology for the planetary boundary layer derived from regular lidar measurements, Atmos. Res., 63, 221-245, doi:10.1016/S0169-8095(02)00043$1,2002$.

Matthias, V., Balis, D., Bosenberg, J., Eixmann, R., Iarlori, M., Komguem, L., Mattis, I., Papayannis, A., Pappalardo, G., Perrone, M. R., and Wang, X.: Vertical aerosol distribution over Europe: Statistical analysis of Raman lidar data from 10 European Aerosol Research Lidar Network (EARLINET) stations, J. Geophys. Res., 109, D18201, doi:10.1029/2004JD004638, 2004.

McConnell, J. R., Edwards, R., Kok, G. L., Flanner, M. G., Zender, C. S., Saltzman, E. S., Banta, J. R., Pasteris, D. R., Carter, M. M., and Kahl, J. D. W.: 20th-century industrial black carbon emissions altered arctic climate forcing, Science, 317, 1381-1384, doi:10.1126/science.1144856, 2007.

McMeeking, G. R., Hamburger, T., Liu, D., Flynn, M., Morgan, W. T., Northway, M., Highwood, E. J., Krejci, R., Allan, J. D., Minikin, A., and Coe, H.: Black carbon measurements in the boundary layer over western and northern Europe, Atmos. Chem. Phys., 10, 9393-9414, doi:10.5194/acp-10-9393-2010, 2010.

Mikhalenko, V., Sokratov, S., Kutuzov, S., Ginot, P., Legrand, M., Preunkert, S., Lavrentiev, I., Kozachek, A., Ekaykin, A., Faïn, X., Lim, S., Schotterer, U., Lipenkov, V., and Toropov, P.: Investigation of a deep ice core from the Elbrus western plateau, the Caucasus, Russia, The Cryosphere, 9, 2253-2270, doi:10.5194/tc-92253-2015, 2015.

Miyakawa, T., Kanaya, Y., Komazaki, Y., Taketani, F., Pan, X., Irwin, M., and Symonds, J.: Intercomparison between a single particle soot photometer and evolved gas analysis in an industrial area in Japan: Implications for the consistency of soot aerosol mass concentration measurements, Atmos. Environ., 127, 14-21, doi:10.1016/j.atmosenv.2015.12.018, 2016.

Mori, T., Moteki, N., Ohata, S., Koike, M., Goto-Azuma, K., Miyazaki, Y., and Kondo, Y.: Improved technique for measuring the size distribution of black carbon particles in liquid water, Aerosol Sci. Technol., 50, 242-254, doi:10.1080/02786826.2016.1147644, 2016.

Moteki, N. and Kondo, Y.: Dependence of Laser-Induced Incandescence on Physical Properties of Black Carbon Aerosols: Measurements and Theoretical Interpretation, Aerosol Sci. Technol., 44, 663-675, doi:10.1080/02786826.2010.484450, 2010.

Moteki, N., Kondo, Y., Oshima, N., Takegawa, N., Koike, M., Kita, K., Matsui, H., and Kajino, M.: Size dependence of wet removal of black carbon aerosols during transport from the boundary layer to the free troposphere, Geophys. Res. Lett., 39, doi:10.1029/2012GL052034, 2012.

Petzold, A., Ogren, J. A., Fiebig, M., Laj, P., Li, S.-M., Baltensperger, U., Holzer-Popp, T., Kinne, S., Pappalardo, G., Sug- 
imoto, N., Wehrli, C., Wiedensohler, A., and Zhang, X.-Y.: Recommendations for reporting "black carbon" measurements, Atmos. Chem. Phys., 13, 8365-8379, doi:10.5194/acp-13-83652013, 2013.

Pio, C. A., Legrand, M., Oliveira, T., Afonso, J., Santos, C., Caseiro, A., Fialho, P., Barata, F., Puxbaum, H., Sanchez-Ochoa, A., Kasper-Giebl, A., Gelencser, A., Preunkert, S., and Schock, M.: Climatology of aerosol composition (organic versus inorganic) at nonurban sites on a west-east transect across Europe, J. Geophys. Res., 112, D23S02, doi:10.1029/2006JD008038, 2007.

Preunkert, S. and Legrand, M.: Towards a quasi-complete reconstruction of past atmospheric aerosol load and composition (organic and inorganic) over Europe since 1920 inferred from Alpine ice cores, Clim. Past, 9, 1403-1416, doi:10.5194/cp-91403-2013, 2013.

Preunkert, S., Wagenbach, D., Legrand, M., and Vincent, C.: Col du Dome (Mt Blanc Massif, French Alps) suitability for ice-core studies in relation with past atmospheric chemistry over Europe, Tellus B, 52, 993-1012, doi:10.1034/j.1600-0889.2000.d01-8.x, 2000.

Preunkert, S., Legrand, M., and Wagenbach, D.: Sulfate trends in a Col du Dome (French Alps) ice core: A record of anthropogenic sulfate levels in the European midtroposphere over the twentieth century, J. Geophys. Res.-Atmos., 106, 31991-32004, doi:10.1029/2001JD000792, 2001.

Rabbinge, R. and van Diepen, C. A.: Changes in agriculture and land use in Europe, Eur. J. Agron., 13, 85-99, doi:10.1016/S1161-0301(00)00067-8, 2000.

Ramanathan, V. and Carmichael, G.: Global and regional climate changes due to black carbon, Nat. Geosci., 1, 221-227, 2008.

Reche, C., Querol, X., Alastuey, A., Viana, M., Pey, J., Moreno, T., Rodríguez, S., González, Y., Fernández-Camacho, R., de la Rosa, J., Dall'Osto, M., Prévôt, A. S. H., Hueglin, C., Harrison, R. M., and Quincey, P.: New considerations for PM, Black Carbon and particle number concentration for air quality monitoring across different European cities, Atmos. Chem. Phys., 11, 6207-6227, doi:10.5194/acp-11-6207-2011, 2011.

Reddington, C. L., McMeeking, G., Mann, G. W., Coe, H., Frontoso, M. G., Liu, D., Flynn, M., Spracklen, D. V., and Carslaw, K. S.: The mass and number size distributions of black carbon aerosol over Europe, Atmos. Chem. Phys., 13, 4917-4939, doi:10.5194/acp-13-4917-2013, 2013.

Schar, C., Vidale, P. L., Luthi, D., Frei, C., Haberli, C., Liniger, M. A., and Appenzeller, C.: The role of increasing temperature variability in European summer heatwaves, Nature, 427, 332336, doi:10.1038/nature02300, 2004.

Schwarz, J. P., Gao, R. S., Fahey, D. W., Thomson, D. S., Watts, L. A., Wilson, J. C., Reeves, J. M., Darbeheshti, M., Baumgardner, D. G., Kok, G. L., Chung, S. H., Schulz, M., Hendricks, J., Lauer, A., Karcher, B., Slowik, J. G., Rosenlof, K. H., Thompson, T. L., Langford, A. O., Loewenstein, M., and Aikin, K. C.: Single-particle measurements of midlatitude black carbon and light-scattering aerosols from the boundary layer to the lower stratosphere, J. Geophys. Res., 111, D16207, doi:10.1029/2006JD007076, 2006.

Schwarz, J. P., Gao, R. S., Spackman, J. R., Watts, L. A., Thomson, D. S., Fahey, D. W., Ryerson, T. B., Peischl, J., Holloway, J. S., Trainer, M., Frost, G. J., Baynard, T., Lack, D. A., de Gouw, J. A., Warneke, C., and Del Negro, L. A.: Measurement of the mixing state, mass, and optical size of individual black carbon particles in urban and biomass burning emissions, Geophys. Res. Lett., 35, L13810, doi:10.1029/2008GL033968, 2008.

Schwarz, J. P., Doherty, S. J., Li, F., Ruggiero, S. T., Tanner, C. E., Perring, A. E., Gao, R. S., and Fahey, D. W.: Assessing Single Particle Soot Photometer and Integrating Sphere/Integrating Sandwich Spectrophotometer measurement techniques for quantifying black carbon concentration in snow, Atmos. Meas. Tech., 5, 2581-2592, doi:10.5194/amt-5-2581-2012, 2012.

Schwarz, J. P., Gao, R. S., Perring, A. E., Spackman, J. R., and Fahey, D. W.: Black carbon aerosol size in snow, Sci. Rep., 3, 1356, doi:10.1038/srep01356, 2013.

Sciare, J., Oikonomou, K., Favez, O., Liakakou, E., Markaki, Z., Cachier, H., and Mihalopoulos, N.: Long-term measurements of carbonaceous aerosols in the Eastern Mediterranean: evidence of long-range transport of biomass burning, Atmos. Chem. Phys., 8, 5551-5563, doi:10.5194/acp-8-5551-2008, 2008.

Seibert, P. and Frank, A.: Source-receptor matrix calculation with a Lagrangian particle dispersion model in backward mode, Atmos. Chem. Phys., 4, 51-63, doi:10.5194/acp-4-51-2004, 2004.

Stephens, M., Turner, N., and Sandberg, J.: Particle identification by laser-induced incandescence in a solid-state laser cavity, Appl. Opt., 42, 3726-3736, 2003.

Stohl, A. and Thomson, D. J.: A Density Correction for Lagrangian Particle Dispersion Models, Bound.-Lay. Meteorol., 90, 155167, doi:10.1023/A:1001741110696, 1999.

Stohl, A., Forster, C., Frank, A., Seibert, P., and Wotawa, G.: Technical note: The Lagrangian particle dispersion model FLEXPART version 6.2, Atmos. Chem. Phys., 5, 2461-2474, doi:10.5194/acp-5-2461-2005, 2005.

Stohl, A., Berg, T., Burkhart, J. F., Fjæraa, A. M., Forster, C., Herber, A., Hov, Ø., Lunder, C., McMillan, W. W., Oltmans, S., Shiobara, M., Simpson, D., Solberg, S., Stebel, K., Ström, J., Tørseth, K., Treffeisen, R., Virkkunen, K., and Yttri, K. E.: Arctic smoke - record high air pollution levels in the European Arctic due to agricultural fires in Eastern Europe in spring 2006, Atmos. Chem. Phys., 7, 511-534, doi:10.5194/acp-7-511-2007, 2007.

Taylor, J. W., Allan, J. D., Allen, G., Coe, H., Williams, P. I., Flynn, M. J., Le Breton, M., Muller, J. B. A., Percival, C. J., Oram, D., Forster, G., Lee, J. D., Rickard, A. R., Parrington, M., and Palmer, P. I.: Size-dependent wet removal of black carbon in Canadian biomass burning plumes, Atmos. Chem. Phys., 14, 13755-13771, doi:10.5194/acp-14-13755-2014, 2014.

Thevenon, F., Anselmetti, F. S., Bernasconi, S. M., and Schwikowski, M.: Mineral dust and elemental black carbon records from an Alpine ice core (Colle Gnifetti glacier) over the last millennium, J. Geophys. Res., 114, D17102, doi:10.1029/2008jd011490, 2009.

Tørseth, K., Aas, W., Breivik, K., Fjæraa, A. M., Fiebig, M., Hjellbrekke, A. G., Lund Myhre, C., Solberg, S., and Yttri, K. E.: Introduction to the European Monitoring and Evaluation Programme (EMEP) and observed atmospheric composition change during 1972-2009, Atmos. Chem. Phys., 12, 5447-5481, doi:10.5194/acp-12-5447-2012, 2012.

Tsyro, S., Simpson, D., Tarrason, L., Klimont, Z., Kupiainen, K., Pio, C., and Yttri, K. E.: Modeling of elemental carbon over Europe, J. Geophys. Res., 112, D23S19, doi:10.1029/2006JD008164, 2007. 
van der Werf, G. R., Randerson, J. T., Giglio, L., Collatz, G. J., Kasibhatla, P. S., and Arellano Jr., A. F.: Interannual variability in global biomass burning emissions from 1997 to 2004, Atmos. Chem. Phys., 6, 3423-3441, doi:10.5194/acp-6-3423-2006, 2006.

van der Werf, G. R., Randerson, J. T., Giglio, L., Collatz, G. J., Mu, M., Kasibhatla, P. S., Morton, D. C., DeFries, R. S., Jin, Y., and van Leeuwen, T. T.: Global fire emissions and the contribution of deforestation, savanna, forest, agricultural, and peat fires (19972009), Atmos. Chem. Phys., 10, 11707-11735, doi:10.5194/acp10-11707-2010, 2010.

Venzac, H., Sellegri, K., Villani, P., Picard, D., and Laj, P.: Seasonal variation of aerosol size distributions in the free troposphere and residual layer at the puy de Dôme station, France, Atmos. Chem. Phys., 9, 1465-1478, doi:10.5194/acp-9-1465-2009, 2009.

Vestreng, V., Myhre, G., Fagerli, H., Reis, S., and Tarrasón, L.: Twenty-five years of continuous sulphur dioxide emission reduction in Europe, Atmos. Chem. Phys., 7, 3663-3681, doi:10.5194/acp-7-3663-2007, 2007.

Vignati, E., Karl, M., Krol, M., Wilson, J., Stier, P., and Cavalli, F.: Sources of uncertainties in modelling black carbon at the global scale, Atmos. Chem. Phys., 10, 2595-2611, doi:10.5194/acp-102595-2010, 2010.

Wang, M., Xu, B., Kaspari, S. D., Gleixner, G., Schwab, V. F., Zhao, H., Wang, H., and Yao, P.: Century-long record of black carbon in an ice core from the Eastern Pamirs: Estimated contributions from biomass burning, Atmos. Environ., 115, 79-88, doi:10.1016/j.atmosenv.2015.05.034, 2015.

Wendl, I. A., Menking, J. A., Färber, R., Gysel, M., Kaspari, S. D., Laborde, M. J. G., and Schwikowski, M.: Optimized method for black carbon analysis in ice and snow using the Single Particle Soot Photometer, Atmos. Meas. Tech., 7, 2667-2681, doi:10.5194/amt-7-2667-2014, 2014.
World Bank Group: The World Bank Data, available at: http://data. worldbank.org/, 2016.

Xu, Y., Ramanathan, V., and Washington, W. M.: Observed highaltitude warming and snow cover retreat over Tibet and the Himalayas enhanced by black carbon aerosols, Atmos. Chem. Phys., 16, 1303-1315, doi:10.5194/acp-16-1303-2016, 2016.

Yoon, J., von Hoyningen-Huene, W., Vountas, M., and Burrows, J. P.: Analysis of linear long-term trend of aerosol optical thickness derived from SeaWiFS using BAER over Europe and South China, Atmos. Chem. Phys., 11, 12149-12167, doi:10.5194/acp11-12149-2011, 2011.

Yoon, J., Burrows, J. P., Vountas, M., von Hoyningen-Huene, W., Chang, D. Y., Richter, A., and Hilboll, A.: Changes in atmospheric aerosol loading retrieved from space-based measurements during the past decade, Atmos. Chem. Phys., 14, 68816902, doi:10.5194/acp-14-6881-2014, 2014.

Yttri, K. E., Aas, W., Bjerke, A., Cape, J. N., Cavalli, F., Ceburnis, D., Dye, C., Emblico, L., Facchini, M. C., Forster, C., Hanssen, J. E., Hansson, H. C., Jennings, S. G., Maenhaut, W., Putaud, J. P., and Tørseth, K.: Elemental and organic carbon in $\mathrm{PM}_{10}$ : a one year measurement campaign within the European Monitoring and Evaluation Programme EMEP, Atmos. Chem. Phys., 7, 5711-5725, doi:10.5194/acp-7-5711-2007, 2007.

Zhou, C., Penner, J. E., Flanner, M. G., Bisiaux, M. M., Edwards, R., and McConnell, J. R.: Transport of black carbon to polar regions: Sensitivity and forcing by black carbon, Geophys. Res. Lett., 39, L22804, doi:10.1029/2012g1053388, 2012. 